\title{
Integrating Simplified and Full Life Cycle Approaches in Decision Making for Building Energy Refurbishment: Benefits and Barriers
}

\author{
Xabat Oregi ${ }^{1, *}$, Patxi Hernandez ${ }^{1}$, Cristina Gazulla ${ }^{2}$ and Marina Isasa ${ }^{2}$ \\ 1 Energy and Environment Division, Tecnalia Research and Innovation, Tecnalia, Azpeitia 20730, \\ Spain; E-Mail: patxi.hernandez@tecnalia.com \\ 2 UNESCO Chair in Life Cycle and Climate Change (ESCI-Pompeu Fabra University), Barcelona 08003, \\ Spain; E-Mails: cristinagaz@gmail.com (C.G.); marina.isasa.sarralde@gmail.com (M.I.) \\ * Author to whom correspondence should be addressed; E-Mail: xabatoregi@gmail.com; \\ Tel.: +34-688-645-028; Fax: +34-901-706-009.
}

Academic Editor: Elma Durmisevic

Received: 2 March 2015 / Accepted: 29 April 2015 / Published: 5 May 2015

\begin{abstract}
The life cycle assessment (LCA) method is a powerful tool that can serve to aid decision making regarding the environmental benefits of refurbishment projects. However, due to the relative complexity of LCA studies, simplified LCA methodologies are frequently used, focusing on just some of the building life cycle phases or a reduced number of indicators. The most common and widespread simplification is to only evaluate the differences a refurbishment project makes on the operational energy use of the building. This paper compares the results of applying full LCA, simplified LCA and operational energy use assessment in a refurbishment case study. Results show that simplified LCA methodologies including building use phase and product manufacturing phase can generally be sufficiently accurate to aid decision making for building energy refurbishment, as other building life cycle phases related to transport of products, on site construction, deconstruction or end of life represent a generally negligible part of the total life cycle impacts, both in terms of resource use or environmental impacts. Barriers and benefits of applying simplified LCA approaches to building energy refurbishment projects are subsequently discussed.
\end{abstract}

Keywords: refurbishment; life cycle assessment (LCA); simplified life cycle assessment; building refurbishment; embodied energy; life cycle energy performance; sensitivity analysis 


\section{Introduction}

Buildings are one of the world's largest energy-consuming sectors, accounting for nearly 30\% of final global energy consumption, reaching $40 \%$ in the European Union (EU) [1]. With new constructions adding at most $1 \%$ a year to the EU existing stock [2], there is large potential for improving the energy performance of the other $99 \%$ of the building stock, making "energy refurbishment" a top priority in current EU and national policies. In the last decade, a remarkable number of studies have focused on quantifying the environmental improvement potential of buildings. Some of these studies [3] focus on the quantification of energy consumption during the use phase of the building, without taking into account the environmental impacts, resources needed and the waste and emissions generated from the building processes. In the cases in which a life cycle approach has been applied on an assessment, there is a general consensus that the use phase contributes more than $80 \%-85 \%$ share in the total life cycle energy use of buildings [4-7]. The study carried out by Karimpour et al. [8] shows that when considering the time value of carbon, in relation to emission targets, the embodied energy (total energy required for the extraction, processing and manufacture of building materials) can represent up to $35 \%$ of the future emissions target of a building in a mild climate. In buildings with a very low energy use in the operational phase, logically other phases of the life cycle like raw materials supply, product manufacturing, transport and installation, and end of life would have a much larger relative impact, becoming the only energy related impact in the so called "zero energy buildings". In that sense, Cellura et al. [9] have emphasized the embodied energy of the building as a key issue to not be neglected in the exhaustive evaluation of the primary energy demand of low energy buildings, whereas according to Lützkendorf et al. [10] the embodied energy of a passive house with PV installation could be $44 \%$ higher than its operation energy for a 60 years lifespan.

From these observations it is clear and generally accepted that when undertaking an environmental assessment of a new building, it is necessary to evaluate all its phases with a life cycle approach, and recent standardization efforts from ISO TC 59/SC17 [11] or CEN TC 350 [12] have developed a methodology and standards to apply this approach in a structured way. However, the effort needed for such analysis is relatively large, and the discussion about whether the evaluation of all building phases is also necessary in building energy refurbishment projects arises. As buildings are extremely complex systems entailing an enormous amount of products, systems, stages and processes, a fully-fledged application of the life cycle assessment (LCA) methodology is still not widely applied, and analysts usually apply some simplifications to reduce the amount of time and facilitate the interpretation of the results. Cabeza et al. [13] and Chau et al. [14], provided a review on comparing life-cycle-based methodologies in the building sector.

In this context and based on a building case study, the main objective of this paper is to verify whether different simplified methodologies currently applied for analyzing building refurbishment strategies are sufficiently reflective of a comprehensive application of the LCA, in terms of reducing resource use and environmental impacts of existing residential buildings. Several sensitivity analyses trying to capture a wide range of potential scenarios have been developed in order to assess the influence of key parameters in the comparison between the different methodologies. 


\section{Methodology and Case Study}

With the aim of identifying to what extent simplifications may influence the results of a decision-making process, three different methodologies, namely LCA, simplified life cycle assessment (LCA-Si) and operational stage assessment (OSA), are applied to the same case study, an existing block of apartments in San Sebastian (Spain). Section 2.1 explains LCA, LCA-Si and OSA methodologies and how are they used by the authors to assess each refurbishment strategy. The case study context, including climate conditions and existing building construction characteristics, are evaluated in Section 2.2, also presenting a diagnosis of the baseline energy performance. Section 2.3 analyzes the selected refurbishment strategies, which have been designed with the objective of decreasing the final heating consumption of the building. Finally, Section 2.4 presents the calculation details for each life cycle phase of the refurbishment strategy.

\subsection{Difference between LCA, LCA-Si and OSA Methodologies}

According to the European Commission Communication on Resource Efficiency Opportunities in the Building Sector [15], the LCA methodology is currently the best framework available to assess the potential environmental impacts of any activity, product or service without geographical, functional or time limits, since it quantifies the environmental impact of the inputs and outputs along its whole life cycle, including the extraction of raw materials, production process, use and end of life stages.

LCA is standardized by ISO 14040 [16] and 14044 [17] standards, and consists of four phases. The first phase is to define the goal and scope of the assessment, which serves as a description of the type of study. The scope of the study determines which processes should be included in the inventory phase of the assessment. In the second phase, the life cycle inventory (LCI) includes information on all of the environmental inputs and outputs associated with a product or service, i.e., material and energy requirements, as well as emissions and waste. The third phase is the impact assessment, where the potential contribution of each substance to predefined environmental impact categories is calculated. Once the impact has been calculated, the fourth and final step of the assessment is the interpretation, where the results of the calculations are summarized and discussed. LCA can choose from several methods to quantify the environmental performance of a product, system or process. For example, the CML method (Centrum voor Milieukunde Leiden) [18] uses indicators at midpoint level showing direct potential impact on the environment situated halfway along the chain of causes and effects. On the other hand, the Eco-indicator method [19] includes endpoint indicators, which represent the ultimate consequences of the environmental impact for humans and ecosystems.

Specifically for the construction sector, new standards, such as EN 15978:2011 [20], already define the different phases of a building life cycle and a number of indicators and methods used to declare the results of the analysis, which are midpoint level (e.g., Global Warming Potential in $\mathrm{kg} \mathrm{CO}_{2}$ equivalent, or Non Renewable Primary Energy Use, in MJ). A description of the building stages defined by EN 15978 is shown in Figure 1. 


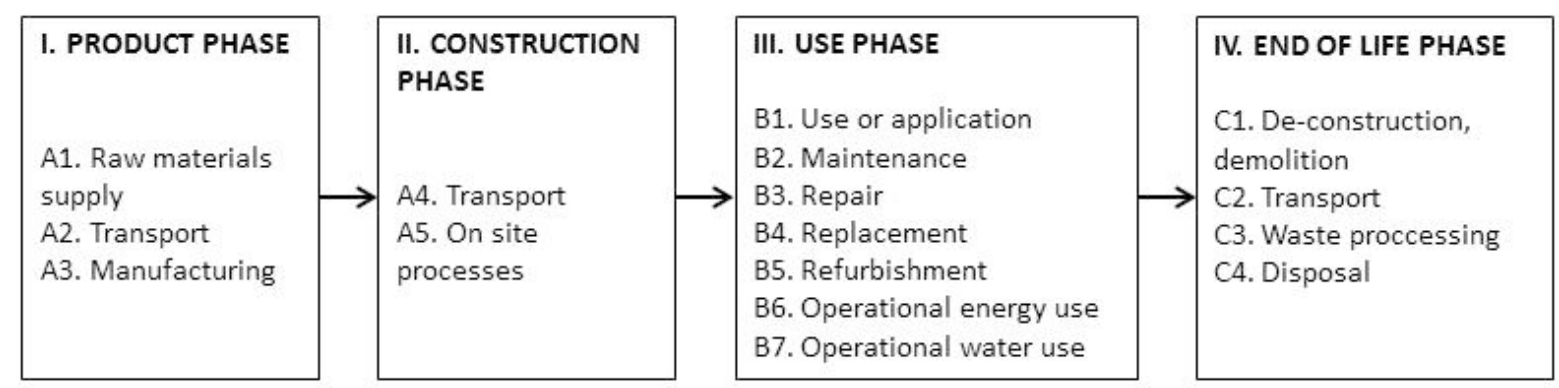

Figure 1. Building stages defined by EN 15978 [20].

Despite the standardization efforts, it is difficult to find published work including all the described life cycle stages, and instead most studies have focused on just some of the stages, i.e., product phase (A1-3) and operational energy use stage (B6). Table 1 shows that very few authors considered all the LCA phases in their studies, being a general trend the omission of some life cycle modules such as on site processes (A5) or maintenance (B2). These omissions are due mainly to the lack of information, the difficulty of predicting future scenarios and the relatively low impact in comparison to the whole life cycle, which according to previous studies [21,22] is less than $1 \%$ for the life cycle energy use. Only some studies assess the replacement phase (B4), which is directly related to the estimated service life (ESL) of each product used which may have a remarkable influence in achieving Life Cycle Zero Energy Buildings (LC-ZEB) [23]. Regarding the calculation method used, it is worth mentioning that a process LCI approach is generally used, except for few studies such us Stephan et al. [24,25] or Kofoworola et al. [26], which use the hybrid LCI analysis.

In order to evaluate the relation between different simplifications and to analyze the influence of these simplifications in the evaluation of a building energy refurbishment, the authors will compare three calculation methodologies: the first methodology is the full LCA methodology (see Table 2), which obviously considers all life cycle stages. The second methodology is a simplified LCA (LCA-Si), focusing only on the evaluation on the product, replacement and operational energy use phases, as applied by Hernandez et al. [23] prior to the definition of the concept of Zero Energy Building with a life cycle approach. Finally, the third methodology is an operational stage assessment (OSA), where the evaluation focuses only on the reduction of the impact during the operational stage of the building. This third methodology is much simpler and generally more accessible to a wider range of technicians, as can be linked with building energy performance evaluation and with building energy rating schemes. 
Table 1. Building Life Cycle Stages in relation to existing studies.

\begin{tabular}{|c|c|c|c|c|c|c|c|c|c|c|}
\hline Building Life Cycle Stages & $\begin{array}{c}\text { Erlandsoona } \\
\text { et al., } 2004 \text { [27] }\end{array}$ & $\begin{array}{l}\text { Junnilla, } \\
2004 \text { [28] }\end{array}$ & $\begin{array}{c}\text { Citherlet et al., } \\
2007 \text { [29] }\end{array}$ & $\begin{array}{c}\text { Zabalza et al., } \\
2009[30]\end{array}$ & $\begin{array}{c}\text { Utama et al., } \\
2009[31]\end{array}$ & $\begin{array}{c}\text { Kofoworola et al., } \\
2009 \text { [26] } \\
\end{array}$ & $\begin{array}{c}\text { Blom et al., } \\
2010 \text { [32] }\end{array}$ & $\begin{array}{c}\text { Blengini } \text { et al., } \\
2010[33] \\
\end{array}$ & $\begin{array}{c}\text { Gustavsoon et al., } \\
2010[34] \\
\end{array}$ & $\begin{array}{c}\text { Hernandez et al., } \\
2010[23]\end{array}$ \\
\hline Product phase (A1-3) & $\mathrm{X}$ & $\mathrm{X}$ & $\mathrm{X}$ & $\mathrm{X}$ & $\mathrm{X}$ & $\mathrm{X}$ & $\mathrm{X}$ & $\mathrm{X}$ & $\mathrm{X}$ & $\mathrm{X}$ \\
\hline Transport (A4) & - & $\mathrm{X}$ & $\mathrm{X}$ & - & $\mathrm{X}$ & $\mathrm{X}$ & $\mathrm{X}$ & $\mathrm{X}$ & $\mathrm{X}$ & - \\
\hline On site processes (A5) & - & $\mathrm{X}$ & - & - & $\mathrm{X}$ & $\mathrm{X}$ & - & $\mathrm{X}$ & - & - \\
\hline Maintenance (B2) & - & $\mathrm{X}$ & $\mathrm{x}$ & - & - & $\mathrm{X}$ & $\mathrm{X}$ & $\mathrm{X}$ & - & - \\
\hline Replacement (B4) & - & - & $\mathrm{X}$ & - & $\mathrm{X}$ & - & $\mathrm{X}$ & $\mathrm{X}$ & - & $\mathrm{X}$ \\
\hline Operational energy use (B6) & $\mathrm{X}$ & $\mathrm{X}$ & $\mathrm{X}$ & $\mathrm{X}$ & $\mathrm{X}$ & $\mathrm{X}$ & $\mathrm{X}$ & $\mathrm{X}$ & $\mathrm{X}$ & $\mathrm{X}$ \\
\hline End of life phase (C1-4) & - & $\mathrm{X}$ & $\mathrm{X}$ & - & - & $\mathrm{X}$ & $\mathrm{X}$ & $\mathrm{X}$ & - & - \\
\hline Building Life Cycle Stages & $\begin{array}{c}\text { Oritz et al., } \\
2010[35]\end{array}$ & $\begin{array}{c}\text { Dodoo et al., } \\
2010[36] \\
\end{array}$ & $\begin{array}{c}\text { Malmqvist } \text { et al., } \\
2011 \text { [37] } \\
\end{array}$ & $\begin{array}{c}\text { Rossi et al., } \\
2012 \text { [38] }\end{array}$ & $\begin{array}{c}\text { Stephan et al., } \\
2012[24]\end{array}$ & $\begin{array}{c}\text { Ramesh et al., } \\
2012 \text { [39] }\end{array}$ & $\begin{array}{c}\text { Stephan et al., } \\
2013 \text { [25] }\end{array}$ & $\begin{array}{c}\text { Mosteiro et al., } \\
2014 \text { [40] } \\
\end{array}$ & $\begin{array}{c}\text { Dodoo et al., } \\
2014 \text { [41] } \\
\end{array}$ & - \\
\hline Product phase (A1-3) & $\mathrm{X}$ & $\mathrm{X}$ & $\mathrm{x}$ & $\mathrm{X}$ & $\mathrm{X}$ & $\mathrm{X}$ & $\mathrm{X}$ & $\mathrm{X}$ & $\mathrm{X}$ & - \\
\hline Transport (A4) & $\mathrm{X}$ & $\mathrm{X}$ & - & $\mathrm{X}$ & $\mathrm{X}$ & $\mathrm{X}$ & $\mathrm{X}$ & $\mathrm{X}$ & & - \\
\hline On site processes (A5) & $\mathrm{x}$ & $\mathrm{X}$ & - & - & $\mathrm{X}$ & $\mathrm{X}$ & $\mathrm{X}$ & $\mathrm{X}$ & $\mathrm{X}$ & - \\
\hline Maintenance (B2) & $\mathrm{x}$ & - & - & - & - & - & - & - & - & - \\
\hline Replacement (B4) & - & - & - & - & $\mathrm{X}$ & $\mathrm{x}$ & $\mathrm{X}$ & $\mathrm{X}$ & - & - \\
\hline Operational energy use (B6) & $\mathrm{X}$ & $\mathrm{X}$ & $\mathrm{X}$ & $\mathrm{X}$ & $\mathrm{X}$ & $\mathrm{X}$ & $\mathrm{X}$ & $\mathrm{X}$ & $\mathrm{X}$ & - \\
\hline End of life phase (C1-4) & $\mathrm{X}$ & $\mathrm{X}$ & - & $\mathrm{X}$ & - & - & - & $\mathrm{X}$ & $\mathrm{X}$ & - \\
\hline
\end{tabular}


Table 2. Building Life Cycle Stages in relation to the three methods considered: Life Cycle Assessment (LCA), simplified LCA (LCA-Si) and Operational Stage Assessment (OSA).

\begin{tabular}{ccccc}
\hline Building Life Cycle Stages & Building Stages & LCA & LCA-Si & OSA \\
\hline A1-3 & Product phase & X & X & - \\
A4 & Transport & X & - & - \\
A5 & On site processes & X & - & - \\
B2 & Maintenance & X & - & - \\
B4 & Replacement & X & X & - \\
B6 & Operational energy use & X & X & X \\
C1-4 & End of life phase & X & - & - \\
\hline
\end{tabular}

\subsection{Case Study}

In order to assess to what extent simplifications in the life cycle calculations may help or mislead decision-making processes, the three methodologies are applied for selecting the best energy refurbishment option for the same building: A residential building built in 1962 in San Sebastian (Spain).

The analysis takes into account the different life cycle phases of the building, starting from the existing scenario and considering a range of refurbishment strategies. A Reference Service Life $\left(R S L_{b}\right)$ of 50 years from the date of refurbishment is considered, a value often used by default, since it is generally difficult to foresee the real life span of a building [37].

The functional equivalent used to compare the different options is the building itself and the results are expressed per year and per unit of useful heated floor area, meeting the conditions of design requirements (thermal comfort, etc.).

From the range of environmental and resource indicators that are used on common LCA, this study will focus for simplicity on one indicator, which is "Use of non-renewable primary energy resources" (in MJ-Eq/functional unit) according to the CML method [18]. A sensitivity analysis for using a range of other environmental indicators on the evaluation is presented in Section 4 of this paper.

\subsubsection{Building Context}

With a total net floor area of $9484 \mathrm{~m}^{2}$ and a heated surface of $8574 \mathrm{~m}^{2}$, the building consists of a commercial ground floor and 9 residential floors (with 12 apartments on each floor), which are heated by a centralized natural gas heating system (see Figure 2). All apartments are naturally ventilated and no cooling or renewable energy systems are installed. $U$-values $\left(\mathrm{W} /\left(\mathrm{m}^{2} \cdot \mathrm{K}\right)\right)$ of the building envelope before its refurbishment include cavity wall façade $1.12 \mathrm{~W} /\left(\mathrm{m}^{2} \cdot \mathrm{K}\right)$, reinforced concrete deck with ceramic finish $2.34 \mathrm{~W} /\left(\mathrm{m}^{2} \cdot \mathrm{K}\right)$, reinforced concrete first floor slab $1.79 \mathrm{~W} /\left(\mathrm{m}^{2} \cdot \mathrm{K}\right)$, monolithic glazing $5.77 \mathrm{~W} /\left(\mathrm{m}^{2} \cdot \mathrm{K}\right)$ and aluminum frame $4.2 \mathrm{~W} /\left(\mathrm{m}^{2} \cdot \mathrm{K}\right)$. These values do not meet the minimum requirements [42] specified by the current national building regulations.

The building is located in San Sebastian, where the annual average temperature is $14{ }^{\circ} \mathrm{C}$. In summer, the daily average temperature is below $20^{\circ} \mathrm{C}$, so cooling systems are generally unnecessary, particularly if measures such as solar shading or night cooling are implemented. In winter, the daily average temperature is about $10^{\circ} \mathrm{C}$, justifying the need for heating systems. 


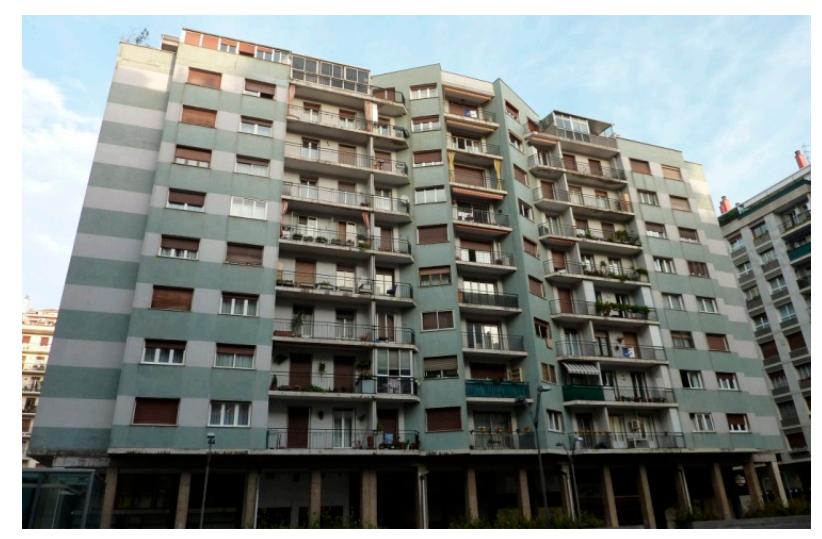

Figure 2. Picture of the case study building.

\subsubsection{Baseline Operational Energy Use}

During their use phase, buildings require operational energy for meeting the demand for heating, cooling, hot water, ventilation, lighting and the use of appliances. However, refurbishment projects such as the one discussed in this paper are focused on the building envelope and aimed at reducing the operational energy use of buildings for heating and cooling, and do not directly affect other building end-uses.

Using the Design Builder [43] software and the International Weather Files for Energy Calculation [44] for the city of San Sebastian, the final energy demand for heating the building before refurbishment was estimated. Being an interface for Energy Plus, Design Builder is a dynamic energy simulation tool that generates detailed data about the energy performance of a building during 1 year by using real weather data as well as temporal aspects such as solar radiation, thermal mass or user occupancy. The building model developed replicates the real geometry, including overhangs, setbacks and the surrounding buildings. Parameters like occupancy rate, schedules, and internal gains have been estimated following current Spanish regulations [42]. For example, a general occupancy value of 0.03 people $/ \mathrm{m}^{2}$ was considered and the common areas (stairs and portals) and ground floor were treated as unheated without occupation or internal gains.

The heating system is composed of a centralized natural gas installation with a nominal performance of 0.92 . Thermostats are set at $21{ }^{\circ} \mathrm{C}$ from 4 p.m. until 11 p.m. for the heating period (from 30 September to 31 May). The baseline operational heating demand calculated according to these parameters is $264 \mathrm{MJ} /\left(\mathrm{m}^{2} \cdot \mathrm{a}\right)$. This demand is multiplied by the system performance and by 1.13 , which is the conversion factor from natural gas to Non-Renewable Primary Energy use (NRPE) in Spain, taken from the Ecoinvent 3.0 database [45]. The resulting baseline operational Non Renewable Primary Energy (NRPE) use for the building is $324 \mathrm{MJ} /\left(\mathrm{m}^{2} \cdot \mathrm{a}\right)$. For the variables in Equation (1), refer to Table 3.

$$
B_{B 6}=\sum_{m=1}^{m} \frac{E D_{b}}{\rho_{m}} \times C F_{m} / H S
$$


Table 3. Variables applied during the calculation of the Non Renewable Primary Energy (NRPE) of each building life cycle phase.

\begin{tabular}{|c|c|c|}
\hline Acronym & Description & Unit \\
\hline$B_{\mathrm{B} 6}$ & Operational energy use of the baseline building & NRPE (MJ) \\
\hline$C E_{\mathrm{A} 5}$ & Energy use associated to construction waste treatment of each refurbishment strategy & NRPE (MJ) \\
\hline$C F_{m}$ & $\begin{array}{l}\text { Conversion factor of the energy source } \mathrm{m} \text { (MJ non renewable primary energy/MJ } \\
\text { final energy) }\end{array}$ & NRPE (MJ) \\
\hline$D_{m}$ & Transport distance of product $\mathrm{m}$ & $\mathrm{km}$ \\
\hline$D W_{m}$ & Transport distance of waste $\mathrm{m}$ from site to waste management facility & $\mathrm{km}$ \\
\hline$E D_{b}$ & Baseline operational annual energy demand & MJ \\
\hline$E D_{m}$ & Operational annual energy demand for the refurbished building & MJ \\
\hline$E E_{m}$ & $\begin{array}{l}\text { Embodied energy of material or system } \mathrm{m} \text { applied during the refurbishment, expressed } \\
\text { per unit of material or system (in } \mathrm{kg}, \mathrm{m}^{2} \text { or } \mathrm{m}^{3} \text { ) }\end{array}$ & NRPE (MJ) \\
\hline$E S L_{m}$ & Estimated service life of the material $\mathrm{m}$ & years \\
\hline$H S$ & Heated surface & $\mathrm{m}^{2}$ \\
\hline$I A_{t}$ & Energy used in the transportation per $\mathrm{t}$ and $\mathrm{km}$ & NRPE (MJ) \\
\hline$I E E_{\mathrm{A} 1-3}$ & Initial embodied energy of each refurbishment strategy & NRPE (MJ) \\
\hline$I E_{\mathrm{A} 4}$ & Initial energy used in the transportation of each refurbishment strategy & NRPE (MJ) \\
\hline$I E_{\mathrm{C} 1-4}$ & Energy use associated to the end of life stage of each refurbishment strategy & NRPE (MJ) \\
\hline$R B_{\mathrm{B} 6}$ & Operational energy use of the refurbished building & NRPE (MJ) \\
\hline$R E E_{\mathrm{B} 4(\mathrm{~A} 1-3)}$ & Recurrent embodied energy of each refurbishment strategy & NRPE (MJ) \\
\hline$R E_{\mathrm{B} 4(\mathrm{~A} 4)}$ & Recurrent energy use associated to the transport of each refurbishment strategy & NRPE (MJ) \\
\hline$R S L_{b}$ & Reference service life of the building & years \\
\hline$Q_{m}$ & Quantity of materials and systems in each refurbishment strategy & $\mathrm{kg}-\mathrm{m}^{2}-\mathrm{m}^{3}$ \\
\hline$Q_{m t}$ & Quantity of material and system in each refurbishment strategy & $\mathrm{t}$ \\
\hline$W P_{m}$ & percentage of waste generated in each refurbishment strategy & $\%$ \\
\hline$W T_{m}$ & Energy use of the waste treatment process per $\mathrm{kg}$ & NRPE (MJ) \\
\hline$\rho_{m}$ & Performance of the energy generation system $\mathrm{m}$ & $\%$ \\
\hline
\end{tabular}

\subsection{Energy Refurbishment Strategies}

In order to reduce the environmental impact related to the building's heating, different energy refurbishment strategies have been evaluated during this study, taking into account that the area where the case study is located shows no historic, urban or architectonic restrictions, allowing direct refurbishment actions on all the envelope elements.

Refurbishment strategies will be applied to the case study in two efficiency levels. The basic efficiency level is based on restoration strategies that enforce the minimum thermal requirements determined by the existing regulations and standards. The advanced efficiency level strategies improve the thermal properties adding insulation to very high values such as those used in standards like the Passive House [46].

Another variable considered for defining refurbishment strategies has been the type of material used, which is important for the life cycle performance particularly in relation to their embodied energy. The strategies have been subsequently divided also by the employment of low and high embodied energy materials. Table 4 details the strategies chosen. 
Table 4. Set of energy refurbishment strategies applied in the case study.

\begin{tabular}{cccc}
\hline \multirow{2}{*}{ Strategy } & Efficiency Level & $\begin{array}{c}\text { Embodied Energy of } \\
\text { Construction Products }\end{array}$ & Strategy ID \\
\hline \multirow{2}{*}{ Window replacement (1) } & \multicolumn{2}{c}{ Basic (b) } & $1 \mathrm{~b}$ \\
& \multirow{2}{*}{ Advanced (a) } & Low (l) & 1a \\
\hline \multirow{2}{*}{ Ventilated façade (2) } & \multirow{2}{*}{ Basic } & High (h) & $2 \mathrm{bh}$ \\
& \multirow{2}{*}{ Advanced } & Low & $2 \mathrm{al}$ \\
& \multirow{2}{*}{ Basic } & High & $2 \mathrm{ah}$ \\
\hline \multirow{2}{*}{ External Insulation System (3) } & & Low & $3 \mathrm{bl}$ \\
& \multirow{2}{*}{ Advanced } & High & $3 \mathrm{bh}$ \\
& \multirow{2}{*}{ Basic } & Low & $3 \mathrm{al}$ \\
& & High & $3 \mathrm{ah}$ \\
\hline \multirow{2}{*}{ Internal (4) } & Advanced & Low & $4 \mathrm{bl}$ \\
& & High & $4 \mathrm{bh}$ \\
& & Low & $4 \mathrm{al}$ \\
& & High & $4 \mathrm{ah}$ \\
\hline
\end{tabular}

The first strategy focuses on the replacement of all existing windows with a new frame and glazing. The windows for the basic energy efficiency level (1b) consist of a double glazing $\left(2.7 \mathrm{~W} /\left(\mathrm{m}^{2} \cdot \mathrm{K}\right)\right)$ and aluminum frame $\left(2.9 \mathrm{~W} /\left(\mathrm{m}^{2} \cdot \mathrm{K}\right)\right)$, meeting the minimum thermal requirements for refurbishments in Spain. The windows for advanced level (1a) consist of a low-emissivity coated glazing $\left(1.4 \mathrm{~W} /\left(\mathrm{m}^{2} \cdot \mathrm{K}\right)\right)$ and wooden frames $\left(1.2 \mathrm{~W} /\left(\mathrm{m}^{2} \cdot \mathrm{K}\right)\right)$. The second solution is a ventilated facade system, which is composed of an aluminum substructure, a layer of insulation and a ceramic outlayer. The third strategy is an external insulation system composed of an insulation layer and mortar outlayer. Finally, the fourth strategy is an indoor thermal improvement solution consisting of a layer of insulation and plasterboard.

According to the efficiency level parameter, different insulation thicknesses are proposed for basic and advanced levels. The projected insulation thicknesses for the basic efficiency energy level are $5 \mathrm{~cm}$ for the façade, $8 \mathrm{~cm}$ for the deck and $6 \mathrm{~cm}$ for the first floor slab. The thicknesses proposed for the advanced energy efficiency level are 25,30 and $15 \mathrm{~cm}$, respectively. Regarding the aluminum profile of the ventilated façade, $10.2 \mathrm{~cm}^{2}$ of aluminum per $\mathrm{m}^{2}$ is projected for the basic level and 49.6 $\mathrm{cm}^{2}$ for the advanced level. Strategies with low embodied energy insulation apply wooden fiber and high embodied energy strategies apply Extruded Polystyrene (XPS) insulation. Regarding the other products that make up the three systems (outlayer, mortar and plasterboard), their properties and quantities are maintained in all cases. It should also be highlighted that secondary products that form part of these strategies, such as screws, sealants, glues are not considered within the scope of the study.

\subsection{Calculation of Non Renewable Primary Energy (NRPE) Use for Each Life Cycle Phase}

\subsubsection{Input Data}

Product Phase (A1-3), Initial Embodied Energy. The embodied energy or initial energy input associated with the production phase of each product and system has been calculated applying Equation (2) (for variables, refer to Table 3) using process data from Ecoinvent [45] and GaBi [47] 
databases as well as Environmental Product Declarations (EPDs) issued by manufacturers (see Table 5).

$$
I E E_{A 1-3}=\sum_{m=1}^{m} E E_{m} \times Q_{m} /\left(R S L_{b} \times H S\right)
$$

Transportation from Production Unit to Point of Use (A4). The transportation of building materials to construction sites involves a variety of transportation modes. Equation (3) describes the calculation of the NRPE use for this stage (for variables, refer to Table 3). Due to the lack of detailed transportation data for each of the materials used to the building site, three different distances are considered (see Table 5): $50 \mathrm{~km}$ (distribution within the province), $120 \mathrm{~km}$ (distribution within the region) and $300 \mathrm{~km}$ (distribution within the same country). The $300 \mathrm{~km}$ value is based on a standard parameter defined in EeB Guide [48], which sets up an average transportation distance in Europe.

$$
I E_{A 4}=\sum_{m=1}^{m} D_{m} \times Q_{m t} \times I A_{t} /\left(R S L_{b} \times H S\right)
$$

Construction Process (A5). Energy use associated with the construction stage of a new envelope is not considered since it typically represents less than $1 \%$ of the life cycle energy demand of the building [21]. However the transportation and end of life treatment processes of the inert and non-hazardous wastes that will be managed in a landfill are considered. For this case study, it is considered that $3 \%$ of the total final product will be wasted during their placement and transported $50 \mathrm{~km}$ to the landfill.

$$
C E_{A 5}=\sum_{m=1}^{m}\left[\left(Q_{m t} \times W P_{m}\right) \times D W_{m} \times I A_{t}\right]+\left[\left(Q_{m t} \times W P_{m}\right) \times W T_{m}\right] /\left(R S L_{b} \times H S\right)
$$

Replacement (B4). Recurrent Embodied Energy (A1-3). As described in Equation, the recurrent embodied energy represents the sum of energy inputs associated with the energy required to manufacture and replace refurbishment materials across the building's service life. Service life and durability of materials are among the most important factors affecting the recurrent embodied energy. In accordance with ISO 15686-8:2008 [49], construction materials and systems usually do not possess the same Estimated Service Life $\left(E S L_{m}\right)$ as the building Reference Service Life $\left(R S L_{b}\right)$ and may require one or multiple replacements over the building's service life. The lower the service life of a material, the greater the quantity of material required for ongoing maintenance and repair and therefore the greater the embodied energy associated with manufacturing and installing replacement materials throughout a building's life. Table 5 shows the values of ESL $m$ applied in this case study, selected according to the information obtained by different EPDs or databases such as National Association of Home Builders (NABH) [50].

$$
R E E_{\mathrm{B} 4(\mathrm{~A} 1-3)}=\sum_{m=1}^{m} E E_{m} \times Q_{m} \times\left(\left(R S L_{b} / E S L_{m}\right)-1\right) /\left(R S L_{b} \times H S\right)
$$

$R S L_{b} / E S L_{m}=1$, No replacement (same or longer material SL than the $R S L_{b}$ ).

$R S L_{b} / E S L_{m}>1$, Replacement is necessary. 
Replacement (B4). Recurrent Transportation from Production Site to Point of Use (A4). Due to the replacement of some products during the $R S L_{b}$ of the case study, the environmental impact related with the transportation process of the additional products is estimated using Equation (6). The same transport distances of the initial transport phase have been used.

$$
R E_{\mathrm{B} 4(\mathrm{~A} 4)}=\sum_{m=1}^{m} D_{m} \times Q_{m t} \times I A_{t} \times\left(\left(R S L_{b} / E S L_{m}\right)-1\right) /\left(R S L_{b} \times H S\right)
$$

Operational Energy Use (B6). As explained before, in this case study focused on refurbishment of the building envelope, the operational energy use only includes the heating of the building during its useful life (see Equation (7)). Other end-uses (hot water production, use of appliances, illumination, etc.), despite being very relevant in an overall building energy use evaluation will not be affected by the proposed refurbishment. The new heating demands of the refurbished building scenarios have been calculated with the same methodology as the baseline operational energy use, i.e., through building energy simulations with Design Builder software.

$$
R B_{\mathrm{B} 6}=\sum_{m=1}^{m} \frac{E D_{m}}{\rho_{m}} \times C F_{m} / H S
$$

End of Life (C1-4). Energy consumption of the end-of-life stage is usually not considered since it typically represents less than $1 \%$ of the life cycle energy of buildings [51]. However, in order to assess all building phases, during this study the transportation of the products (initial and recurrent) to the waste treatment facility and their management is evaluated (see Equation (8)). For this case study, road transportation during $50 \mathrm{~km}$ to the landfill for inert and non-hazardous waste is considered. Being beyond the scope of the study, potential recycling or reuse of the aluminum used in the frame of the windows (strategy 1) and in the ventilated facade sub-structure (strategy 2) is not included.

$$
I E_{C 1-4}=\sum_{m=1}^{m}\left(Q_{m t} \times D W_{m} \times I A_{t}\right)+\left(Q_{m t} \times W T_{m}\right) /\left(R S L_{b} \times H S\right)
$$

Table 5 shows information about the parameter applied to evaluate the NRPE use for each product and process that participates in different refurbishment strategies, allowing the calculation of the impact of each Life Cycle Phase.

\begin{tabular}{|c|c|c|c|c|c|}
\hline \multirow{2}{*}{ Product/Process } & \multicolumn{2}{|c|}{ Non Renewable Primary Energy Use } & \multirow{2}{*}{$\begin{array}{c}\text { Transport } \\
(\mathbf{k m})\end{array}$} & \multicolumn{2}{|r|}{$\mathbf{E S L}_{\mathbf{m}}$} \\
\hline & Value & Data Source & & Years & Data Source \\
\hline Double glazed & $463\left(\mathrm{MJ} / \mathrm{m}^{2}\right)$ & $\begin{array}{l}\text { INIES-FDES } \\
\text { SGG Climaplus [52] }\end{array}$ & Truck-120 & 30 & $\begin{array}{c}\text { Environmental Product } \\
\text { Declaration (EPD) }\end{array}$ \\
\hline Triple glazed & $707\left(\mathrm{MJ} / \mathrm{m}^{2}\right)$ & $\begin{array}{l}\text { INIES-FDES. } \\
\text { SGG Climatop [53] }\end{array}$ & Truck-300 & 30 & EPD \\
\hline Aluminum frame & $1852\left(\mathrm{MJ} / \mathrm{m}^{2}\right)$ & $\begin{array}{l}\text { GaBi. Aluminum wing profile, powder } \\
\text { coated PE (2010) }\end{array}$ & Truck-50 & 20 & $\begin{array}{l}\text { National Association of } \\
\text { Home Builders (NAHB) }\end{array}$ \\
\hline
\end{tabular}

Table 5. Non Renewable Primary Energy (NRPE), Transport characteristics, and Estimated Service Life of the materials $\left(E S L_{m}\right)$ for products and processes included in the analysis. 
Table 5. Cont.

\begin{tabular}{|c|c|c|c|c|c|}
\hline \multirow{2}{*}{ Product/Process } & \multicolumn{2}{|c|}{ Non Renewable Primary Energy Use } & \multirow{2}{*}{$\begin{array}{c}\text { Transport } \\
(\mathbf{k m})\end{array}$} & \multicolumn{2}{|c|}{$\mathbf{E S L}_{\mathbf{m}}$} \\
\hline & Value & Data Source & & Years & Value \\
\hline Wood frame & $206\left(\mathrm{MJ} / \mathrm{m}^{2}\right)$ & ENVIRONDEC-Cormo [54] & Truck-300 & 30 & EPD \\
\hline $\begin{array}{l}\text { Aluminum } \\
\text { sub-structure }\end{array}$ & $118(\mathrm{MJ} / \mathrm{kg})$ & $\begin{array}{l}\text { GaBi. Aluminum } \\
\text { extrusion profile PE (2010) }\end{array}$ & Truck-120 & 50 & NAHB \\
\hline Insulation (high) & $92.4(\mathrm{MJ} / \mathrm{kg})$ & $\begin{array}{l}\text { Ecoinvent. Polystyrene, } \\
\text { extruded (XPS), at plant }\end{array}$ & Truck-50 & 50 & NAHB \\
\hline Insulation (low) & $5\left(\mathrm{MJ} / \mathrm{m}^{3}\right)$ & $\begin{array}{l}\text { GaBi. Lightweight } \\
\text { wood fibers panel PE (2010) }\end{array}$ & Truck-300 & 50 & NAHB \\
\hline Outlayer & $256\left(\mathrm{MJ} / \mathrm{m}^{2}\right)$ & $\begin{array}{l}\text { GaBi. Ceramic façade } \\
\text { panels_-NBK Ceramic PE (2008) }\end{array}$ & Truck-120 & 50 & NAHB \\
\hline Mortar & $1.3(\mathrm{MJ} / \mathrm{kg})$ & Ecoinvent. Cement mortar, at plant & Truck-50 & 35 & NAHB \\
\hline Plasterboard & $54\left(\mathrm{MJ} / \mathrm{m}^{2}\right)$ & Ecoinvent. Gypsum plaster board, at plant & Truck-120 & 30 & NAHB \\
\hline Transport-truck & $0.8(\mathrm{MJ} /(\mathrm{t} \cdot \mathrm{km}))$ & $\begin{array}{l}\text { GaBi. Articulated lorry (40t) incl. fuel } \\
\text { ELCD (2005) }\end{array}$ & - & - & - \\
\hline Landfill & $0.2(\mathrm{MJ} / \mathrm{kg})$ & $\begin{array}{l}\text { GaBi. Landfill for inert matter } \\
\text { (construction waste) (2010) }\end{array}$ & - & - & - \\
\hline
\end{tabular}

2.4.2. Sample Calculation of Non Renewable Primary Energy (NRPE) Use for one of the Energy Refurbishment Strategies

As an example, in this section, the environmental calculation of a proposed rehabilitation strategy $(1 \mathrm{a}+2 \mathrm{ah})$ is explained. This strategy focuses on replacing existing windows with $204 \mathrm{~m}^{2}$ of new wooden frames $(11,526 \mathrm{~kg})$ and $1018 \mathrm{~m}^{2}$ of triple glazing $(34,917 \mathrm{~kg})$. The façade will be refurbished with a ventilated façade system, which consists of $5581 \mathrm{~m}^{2}$ of $25 \mathrm{~cm}$ XPS insulation $(60,275 \mathrm{~kg})$, $12,830 \mathrm{~kg}$ of Aluminum sub-structure with a section of $49.6 \mathrm{~cm}^{2}$ and $4409 \mathrm{~m}^{2}$ of ceramic façade panels $(60,274 \mathrm{~kg})$. Through this information, and the values previously defined in Table 5 (BB $6, R S L_{b}, E S L_{m}$, $E E_{m}, D_{m}, Q_{m}, Q_{m t}, I A_{t}, D W_{m}, C F_{m}$ and $\rho_{m}$ ), the authors have performed the calculation of the NRPE use of each of the life cycle phases of this strategy.

Figure 3 shows that the NRPE use of the building after applying the refurbishment strategy $1 \mathrm{a}+2 \mathrm{ah}$ is reduced from $324 \mathrm{MJ} /\left(\mathrm{m}^{2} \cdot \mathrm{a}\right)$ to $92 \mathrm{MJ} /\left(\mathrm{m}^{2} \cdot \mathrm{a}\right)$, reaching a reduction of $72 \%$, which is mostly due to the operational energy use phase $\left(69.6 \mathrm{MJ} /\left(\mathrm{m}^{2} \cdot \mathrm{a}\right)\right)$ and the Initial Embodied Energy phase $\left(20.93 \mathrm{MJ} /\left(\mathrm{m}^{2} \cdot \mathrm{a}\right)\right)$. 


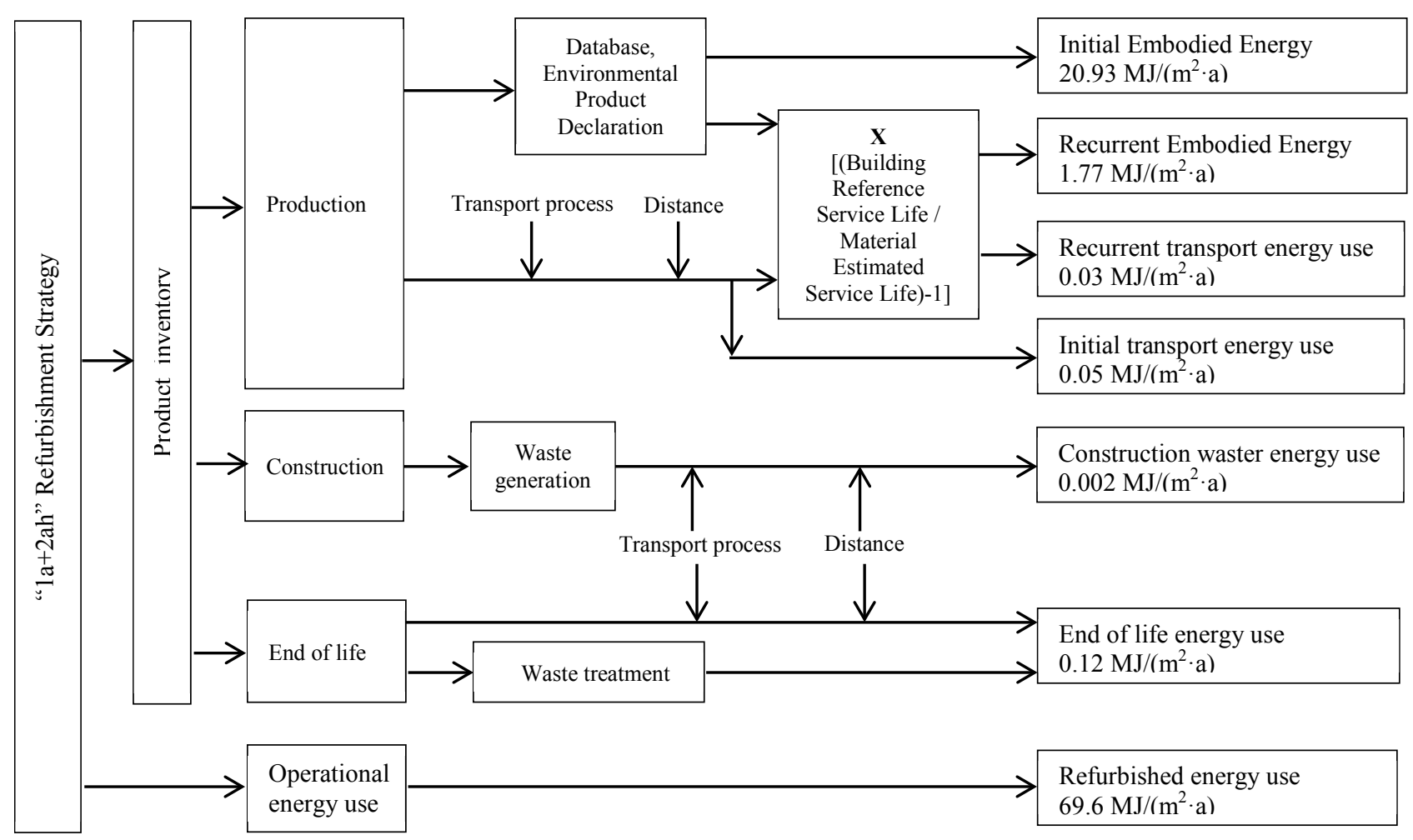

Figure 3. Scheme of inputs and Non Renewable Primary Energy (NRPE) use of each life cycle phase of the 1a +2 ah energy refurbishment strategy.

\section{Results}

\subsection{Life Cycle Energy Performance Evaluation-NRPE Results}

Applying the same calculation procedure for all energy rehabilitation strategies, the NRPE use of each phase was obtained. Figure 4 shows, in comparison with the baseline scenario, the decrease on the NRPE during the operational stage and the increase of NRPE derived from the production, transportation, construction, replacement and end of life phases of the products and systems applied in each refurbishment strategy.

For the particular building studied, Table 6 shows that the refurbishment option with the highest NRPE use reduction (i.e., 77\%) calculated with the LCA methodology is strategy "1a + 3al", which increases the building envelope insulation level and replaces the current glazing with double-glazed low-emissivity coated window. Results show that the influence of the constructive characteristics and embodied energy parameters is very low, being the advanced level refurbishment strategies the most effective and efficient to reduce the baseline NRPE use. As for the refurbishment option with the highest reduction on energy use according the OSA methodology (only considering operational stage of the building), " $1 \mathrm{a}+2 \mathrm{al}$ ", " $1 \mathrm{a}+2 \mathrm{ah}$ ", " $1 \mathrm{a}+3 \mathrm{al}$ ", and " $1 \mathrm{a}+3 \mathrm{ah}$ " strategies present the same result, as differences amongst them occur in other life cycle stages.

As expected the reduction of life cycle NRPE is much larger than the energy consumed by the different refurbishment strategies. The ratio between the increase and decrease on NRPE reach up to $15 \%$, for strategies using products with higher embodied energy (i.e., 2ah strategy). Consequently, the ratio has lower values (up to $0.12 \%$ ) when the products applied have lower embodied energy (i.e., $3 b l$ strategy). 
NRPE attributed to the replacement phase represents less than $5 \%$ of the decrease on operational NRPE, whereas NRPE attributed to the transportation (initial and recurrent), construction and end of life phases (neither of which is covered by the LCA-Si method), do not reach $0.19 \%$ of the NRPE reduction. Detailed values for the NRPE indicator for each of the refurbishment strategies and each of the calculation methodologies are presented in Table 6.

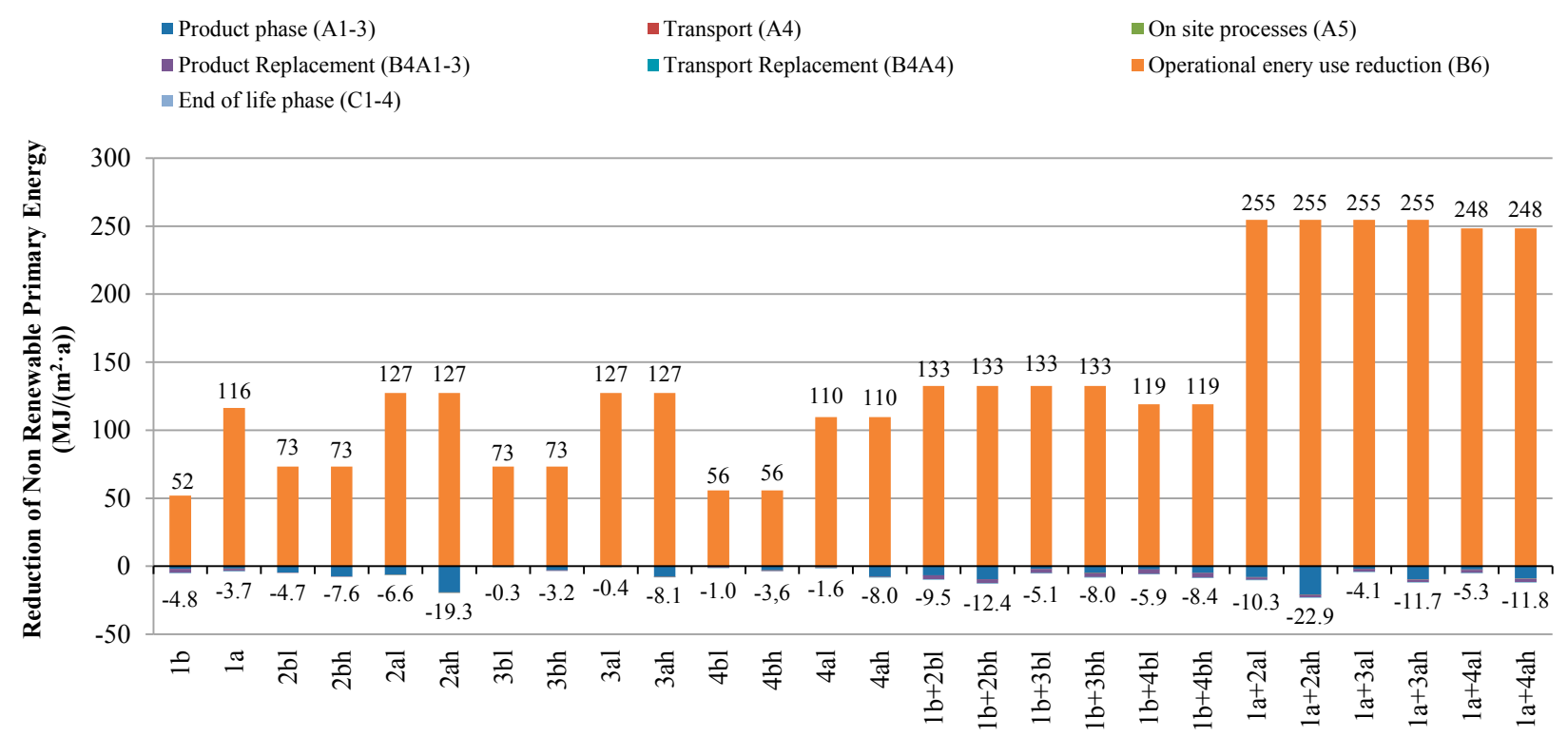

Figure 4. Reduction of Non Renewable Primary Energy use $\left(\mathrm{MJ} /\left(\mathrm{m}^{2} \cdot \mathrm{a}\right)\right)$ from each refurbishment strategy in relation to the baseline. Positive values indicate a reduction of energy use on the operational phase. Negative values represent the energy use on the rest of the life cycle phases.

Table 6. Reduction of Non Renewable Primary Energy use of each refurbishment strategy according to Life Cycle Assessment (LCA), simplified LCA (LCA-Si) and Operational Stage Assessment (OSA) $\left(\mathrm{MJ} /\left(\mathrm{m}^{2} \cdot \mathrm{a}\right)\right)$.

\begin{tabular}{cccccccc}
\hline Strategy & LCA & LCA-Si & OSA & Strategy & LCA & LCA-Si & OSA \\
\hline 1b & 47.1 & 47.1 & 51.9 & $\mathbf{1 b}+\mathbf{2 b l}$ & 123.1 & 123.1 & 132.6 \\
1a & 112.6 & 112.7 & 116.2 & $\mathbf{1 b}+\mathbf{2 b h}$ & 120.2 & 120.2 & 132.6 \\
2bl & 68.6 & 68.6 & 73.3 & $\mathbf{1 b}+\mathbf{3 b l}$ & 127.4 & 127.4 & 132.6 \\
2bh & 65.7 & 65.7 & 73.3 & $\mathbf{1 b}+\mathbf{3 b h}$ & 124.6 & 124.6 & 132.6 \\
2al & 120.8 & 121.3 & 127.4 & $\mathbf{1 b}+\mathbf{4 b l}$ & 113.3 & 113.3 & 119.2 \\
2ah & 108.2 & 108.3 & 127.4 & $\mathbf{1 b}+\mathbf{4 b h}$ & 110.7 & 110.7 & 119.2 \\
3bl & 73.0 & 73.0 & 73.3 & $\mathbf{1 a}+\mathbf{2 a l}$ & 244.4 & 245.0 & 254.7 \\
3bh & 70.1 & 70.1 & 73.3 & $\mathbf{1 a}+\mathbf{2 a h}$ & 231.8 & 232.0 & 254.7 \\
3al & 127.0 & 127.1 & 127.4 & $\mathbf{1 a}+\mathbf{3 a l}$ & 250.6 & 250.8 & 254.7 \\
3ah & 119.4 & 119.4 & 127.4 & $\mathbf{1 a}+\mathbf{3 a h}$ & 243.0 & 243.2 & 254.7 \\
4bl & 54.7 & 54.7 & 55.7 & $\mathbf{1 a}+\mathbf{4 a l}$ & 243.3 & 243.9 & 248.4 \\
4bh & 52.1 & 52.1 & 55.7 & $\mathbf{1 a}+\mathbf{4 a h}$ & 236.7 & 237.0 & 248.4 \\
4al & 108.3 & 108.7 & 109.7 & - & - & - & - \\
4ah & 101.7 & 101.8 & 109.7 & - & - & - & - \\
\hline
\end{tabular}




\subsection{Comparison of LCA, LCA-Si and OSA Methodologies}

In order to evaluate the influence of the methodological simplifications in a building energy refurbishment decision making process, the difference between the OSA and LCA-Si from a full LCA is expressed as a relative difference (see Equations (9) and (10)) in Figure 5.

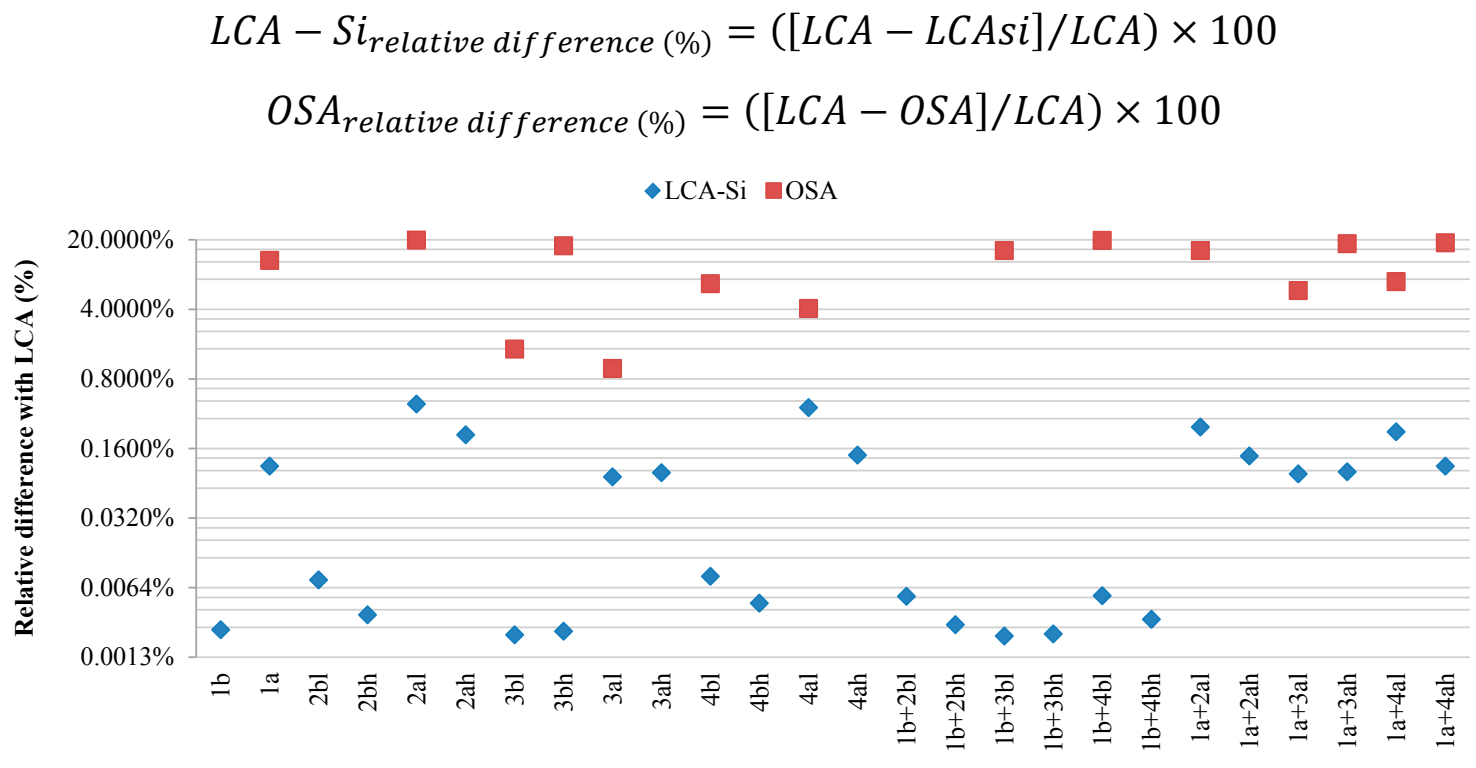

Figure 5. Relative difference of LCA-Si and OSA with LCA.

The values of Figure 5 shows that for this case study and for the selected NRPE indicator, the difference between the results obtained with LCA and LCA-Si methodologies is below $0.39 \%$. However, the results obtained with the OSA methodology in comparison with LCA present differences varying from $0.34 \%$ (for 3al strategy) to $15 \%$ (for 2ah strategy). Higher differences occur in the case of strategies using products with higher embodied energy associated.

\section{Sensitivity and Uncertainty Evaluation}

With the aim of drawing a general conclusion that offers an overview of residential building refurbishment actions, a sensitivity analysis tackling different relevant aspects is conducted in this section. In order to simplify and facilitate the reading of the results, the study only reflects the results for the strategies $2 \mathrm{ah}$ and 3al, which presented the largest and lowest percentage differences on the results when analyzed respect the LCA methodology.

\subsection{Reference Service Life of the Building (RSLb)}

The annualized NRPE use has been assessed for different $R S L_{b}$ values: 25, 50 (current scenario), 75 and 100 years. Table 7 shows that the difference between the results obtained by LCA and OSA methodologies increases when $R S L_{b}$ is lower, up to a difference of $30.24 \%$ in strategy 2 ah. This difference falls to $0.36 \%$ for strategies applying products with lower embodied energy and when the same $R S L_{b}$ (25 years) is applied. Regarding the difference between the LCA and LCA-Si methodologies, the lower $R S L_{b}$ value, and the greater the difference. However differences between these two methodologies are in all cases below $1 \%$. 
Table 7. Sensitivity analysis results for refurbishment strategies 2 ah (advanced efficiency level ventilated façade system with high embodied energy products and 3al (advanced efficiency level external insulation system with low embodied energy products).

\begin{tabular}{|c|c|c|c|c|c|c|c|}
\hline \multicolumn{8}{|c|}{ Non Renewable Primary Energy use Reduction $\left(\mathrm{MJ} /\left(\mathrm{m}^{2} \cdot \mathbf{a}\right)\right)$} \\
\hline \multirow{2}{*}{ Variable } & \multicolumn{3}{|c|}{ 2ah Strategy } & \multirow{2}{*}{ Variable } & \multicolumn{3}{|c|}{ 3al Strategy } \\
\hline & LCA & LCA-Si & OSA & & LCA & LCA-Si & OSA \\
\hline \multicolumn{8}{|c|}{ Reference Service Life Building $\left(R S L_{b}\right)$} \\
\hline$R S L_{25}$ & 89.1 & 89.1 & 127.4 & $R S L_{25}$ & 127.1 & 127.1 & 127.4 \\
\hline$R S L 50$ & 108.2 & 108.3 & 127.4 & $R S L_{50}$ & 127.0 & 127.1 & 127.4 \\
\hline $\mathrm{RSL}_{75}$ & 114.5 & 114.7 & 127.4 & $\mathrm{RSL}_{75}$ & 127.0 & 127.1 & 127.4 \\
\hline$R S L_{100}$ & 117.8 & 117.9 & 127.4 & $R S L_{100}$ & 127.1 & 127.2 & 127.4 \\
\hline \multicolumn{8}{|c|}{ Estimated Service Life Materials $\left(E S L_{m}\right)$} \\
\hline$E S L_{\text {half }}$ & 88.9 & 89.1 & 127.4 & ESL $_{h a l f}$ & 126.8 & 126.9 & 127.4 \\
\hline$E S L_{\text {current }}$ & 108.2 & 108.3 & 127.4 & ESLcurrent & 127.0 & 127.1 & 127.4 \\
\hline$E S L 50$ years & 108.2 & 108.3 & 127.4 & ESL50 years & 127.2 & 127.3 & 127.4 \\
\hline \multicolumn{8}{|c|}{ Product Transport Distance $\left(D_{m}\right)$} \\
\hline$D m_{50}$ & 108.2 & 108.3 & 127.4 & $D m_{50}$ & 127.1 & 127.1 & 127.4 \\
\hline$D m_{120}$ & 108.2 & 108.3 & 127.4 & $D m_{120}$ & 127.0 & 127.1 & 127.4 \\
\hline$D_{300}$ & 108.1 & 108.3 & 127.4 & $D_{300}$ & 127.0 & 127.1 & 127.4 \\
\hline$D m_{500}$ & 108.1 & 108.3 & 127.4 & $\mathrm{Dm}_{500}$ & 126.9 & 127.1 & 127.4 \\
\hline$D m_{1000}$ & 107.9 & 108.3 & 127.4 & $D m_{1000}$ & 126.8 & 127.1 & 127.4 \\
\hline Dm2000 & 107.7 & 108.3 & 127.4 & Dm2000 & 126.6 & 127.1 & 127.4 \\
\hline Dm5000 & 106.8 & 108.3 & 127.4 & Dm5000 & 125.8 & 127.1 & 127.4 \\
\hline \multicolumn{8}{|c|}{ Climate Zone } \\
\hline Current & 108.2 & 108.3 & 127.4 & Current & 127.0 & 127.1 & 127.4 \\
\hline Cold & 233.8 & 233.9 & 253.1 & Cold & 252.7 & 252.8 & 253.1 \\
\hline Warm & 59.3 & 59.4 & 78.6 & Warm & 78.1 & 78.2 & 78.6 \\
\hline \multicolumn{8}{|c|}{ Life Cycle Inventory } \\
\hline LCI-Process & 108.2 & 108.3 & 127.4 & LCI-Process & 127.0 & 127.1 & 127.4 \\
\hline LCI-Hybrid & 49.7 & 50.2 & 127.4 & LCI-Hybrid & 125.6 & 126.2 & 127.4 \\
\hline \multicolumn{8}{|c|}{ Operational Energy Use } \\
\hline$+20 \%$ & 131.7 & 131.8 & 151.0 & $+20 \%$ & 150.6 & 150.7 & 151.0 \\
\hline$-20 \%$ & 72.8 & 72.9 & 92.1 & $-20 \%$ & 91.7 & 91.8 & 92,1 \\
\hline
\end{tabular}

\subsection{Estimated Service Life of the Products (ESL $)$}

ESLm values for each product and system where defined for the baseline scenario (see Table 5). However, depending on the real use and maintenance practices, these values may be reduced or increased and, therefore, two additional ESLm are assessed: Reducing the lifetime of all products by half and increasing their life by up to 50 years. Table 7 shows that the reduction of the ESLm increases the difference between the LCA and OSA methodologies, obtaining a difference of up to $30.2 \%$ in $2 \mathrm{ah}$ strategy. On the other hand, for the same strategy, ESL 50 year values reduce the difference to $15.11 \%$. For those refurbishment strategies using products with a lower embodied energy the difference decreases but continues below $0.5 \%$. 


\subsection{Transportation Distance}

Transportation distance values from the production gate to the building site have been changed to $50,120,300,500,1000,2000$ and $5000 \mathrm{~km}$. Table 7 clearly shows that except in very long distances (5000 $\mathrm{km}$ or more), the transportation distance of the products does not alter the initial results obtained from the different methodologies. Furthermore, although all products and systems are transported from $5000 \mathrm{~km}$, the overall NRPE use of the building will only be $0.01 \%$ higher than in a scenario where all products and systems are transported within a distance of $50 \mathrm{~km}$. Although these results reflect that transport distance is practically irrelevant for reducing the NRPE use, it is worth noting that transport may have remarkable contributions to other environmental impact categories related to air quality or noise, as well as in economic terms where transport costs are also relevant.

\subsection{Climate Zone}

In order to check the influence of applying the same refurbishment strategies in other climate zones, two additional climate zones are evaluated: Warm climate (south of Italy, Palermo) and cold climate (Norway, Oslo). Due to the relevance of cooling consumption in warm climates, in this case the operational energy includes energy consumption for both heating and cooling indoor spaces (see Equation (7)). The cooling system consists of individual air-air electric installations with a nominal performance of 3 ( $\rho_{m}$ value). Thermostats are set at $26^{\circ} \mathrm{C}$ from 12 a.m. until 8 p.m. for the cooling period (from 1 June to 31 August). To calculate the cooling related Non-Renewable Primary Energy use (NRPE), the demand is multiplied by the system performance and by a conversion factor value of 2.34 corresponding to an average value for the electricity mix in Europe [55].

Table 7 shows that in countries with a cold climate, refurbishment strategies lead to high reductions of NRPE during the use phase, and therefore the influence of other life cycle stages is reduced. The maximum difference between LCA and OSA results to $8.5 \%$ (strategy 2ah) for cold climates. In warm climates with a lower heating demand, the difference between LCA and OSA results to $32 \%$ (strategy 2ah), because the NPRE increase due to the use of products is relatively higher.

\subsection{Uncertainty on Data on Embodied Energy of Products}

Most current studies, including the present one, use environmental data from LCI databases and/or environmental product declarations, which are based on the LCA methodology for calculating the environmental inputs and outputs of each process involved in the corresponding supply chain (bottom-up technique). This process based LCA approach may conduct to a large associated uncertainty [56] due to the truncation error derived from data scarcity at a certain point of the upstream supply chain. Crawford [57] has shown that this error can be up to $87 \%$ of the embodied energy of building products, and has proposed the use of input-output LCA analysis, a top-down technique that establishes a link between economic transactions and the energy intensity of economic sectors, or hybrid LCA analysis, combining process and input-output analysis, to capture all the upstream processes. Crawford [58], Crawford and Stephan [59] and Stephan and Stephan [60] have shown that input-output-based hybrid analysis can produce embodied energy figures around four times higher than process analysis, for the same building. In order to assess the effect of a potential underestimation of the embodied energy 
values, a new scenario has been calculated multiplying the energy values by an average coefficient of 4.03 [60].

When data derived from hybrid LCA studies is used instead of process-based data, the difference between LCA and OSA increases, reaching a maximum difference of $60.5 \%$ for strategies with highest embodied energy values. This large difference on the results respond to the much high values of NRPE for building products that are obtained through LCI-hybrid methods. With these values, the overall reduction of NRPE for the LCI-Hybrid method is less than half the reduction obtained with the LCI-Process method for the LCA and LCA-Si.

\subsection{Uncertainty in Relation to Occupancy Schedules and User Behavior}

Occupancy schedules may significantly vary the results of operational energy use. This parameter adds a remarkable uncertainty to the results, as it has a critical role when estimating energy loads in residential buildings, as shown for example by Topouzi [61]. Indeed, Pettersen [22] and Juodis et al. [62] have shown that user behavior could vary the primary operational energy associated with space heating by $\pm 15 \%-20 \%$. Therefore, two new scenarios have been added to take these issues into account, assuming that the heating demand of the baseline scenario can be $20 \%$ higher and $20 \%$ lower than initially calculated due to occupancy and behavioral issues. Table 7 shows that when the operational energy consumption increases, the difference between LCA and OSA decreases, and vice versa.

\subsection{Sensitivity Analysis for a Combination of Different Factors}

In order to explore additional potential situations, 32 new refurbishment scenarios were assessed by combining extreme values for the different parameters evaluated separately in the previous sections (see Table 8). Taking into account the low influence of the material transportation distance (less than $0.01 \%$ ), this parameter was not included in the combination of different factors.

For simplicity, Figure 6 shows the relative difference with LCA of the results obtained with LCA-Si and OSA for those refurbishment strategies with the highest and the lowest difference in their parameter values: $2 \mathrm{ah}$ and $3 \mathrm{al}$, respectively.

As presented in Figure 6, for almost all the additional scenarios differences obtained using LCA and LCA-Si methodologies are lower than 3\%. However, new scenarios highlight the differences between LCA/LCA-Si with OSA, which can reach up to $319 \%$ in buildings located in warm climates and by the application of hybrid embodied energy data. The second lecture of the Figure 6 is related to the embodied energy of applied products. The results show that the relative difference between LCA and OSA in refurbishment strategies with low embodied energy products is lower that $4 \%$, except in scenarios such as $\mathrm{C} 1$ and $\mathrm{C} 9$ (with a relative difference of $4.1 \%, 5.4 \%$ respectively). However, in refurbishment strategies with high embodied energy, the difference between LCA and OSA in considerable, increasing the importance of obtaining objective and actual information about each product, and therefore showing the relevance of the application of hybrid data, which can have much higher embodied energy values.

Regarding service life, in energy refurbishment projects with high $R S L_{b}$ and low $E S L_{m}$ values, the difference between these LCA and OSA methodologies is greater than $35 \%(\mathrm{C} 1, \mathrm{C} 3, \mathrm{C} 5, \mathrm{C} 17$ and 
C51). However, in climate zones with high operational heating energy demand, this difference is decreased to $5.6 \%(\mathrm{C} 23)$.

Table 8. Definition of new energy refurbishment scenarios by the combination of different Reference Service Life of buildings $\left(R S L_{b}\right)$, Estimated Service Life of material $\left(E S L_{m}\right)$, Climate zone $(\mathrm{Cl})$, type of Embodied Energy data $(E E)$ and Operational Energy use uncertainties $(O E)$.

\begin{tabular}{|c|c|c|c|c|c|c|c|c|c|c|}
\hline \multirow{2}{*}{ Scenario ID } & \multicolumn{2}{|c|}{$R S L_{b}$ (years) } & \multicolumn{2}{|c|}{$E S L_{m}$ (years) } & \multicolumn{2}{|c|}{$\mathrm{Cl}$} & \multicolumn{2}{|c|}{$E E$} & \multicolumn{2}{|c|}{$O E$} \\
\hline & 100 & 25 & Half & 50 & Warm & Cold & Hybrid & Process & $-20 \%$ & $+20 \%$ \\
\hline C1 & $\mathrm{X}$ & - & $\mathrm{X}$ & - & X & - & X & - & $\mathrm{X}$ & - \\
\hline $\mathrm{C} 2$ & $\mathrm{X}$ & - & - & $X$ & $X$ & - & $X$ & - & $X$ & - \\
\hline $\mathrm{C} 3$ & $\mathrm{X}$ & - & $\mathrm{X}$ & - & - & $X$ & $X$ & - & $\mathrm{X}$ & - \\
\hline $\mathrm{C} 4$ & $\mathrm{X}$ & - & - & $X$ & - & $X$ & $X$ & - & $\mathrm{X}$ & - \\
\hline C5 & $\mathrm{X}$ & - & $X$ & - & $X$ & - & - & $\mathrm{X}$ & $\mathrm{X}$ & - \\
\hline C6 & $\mathrm{X}$ & - & - & $X$ & $\mathrm{X}$ & - & - & $\mathrm{X}$ & $X$ & - \\
\hline C7 & $X$ & - & $\mathrm{X}$ & - & - & $\mathrm{X}$ & - & $\mathrm{X}$ & $\mathrm{X}$ & - \\
\hline C8 & $\mathrm{X}$ & - & - & $X$ & - & $\mathrm{X}$ & - & $\mathrm{X}$ & $X$ & - \\
\hline C9 & - & $X$ & $\mathrm{X}$ & - & $X$ & - & $\mathrm{X}$ & - & $\mathrm{X}$ & - \\
\hline $\mathrm{C} 10$ & - & $\mathrm{X}$ & - & $\mathrm{X}$ & $\mathrm{X}$ & - & $\mathrm{X}$ & - & $\mathrm{X}$ & - \\
\hline C11 & - & $X$ & $\mathrm{X}$ & - & - & $X$ & $X$ & - & $X$ & - \\
\hline $\mathrm{C} 12$ & - & $\mathrm{X}$ & - & $\mathrm{X}$ & - & $\mathrm{X}$ & $\mathrm{X}$ & - & $\mathrm{X}$ & - \\
\hline $\mathrm{C} 13$ & - & $X$ & $\mathrm{X}$ & - & $X$ & - & - & $\mathrm{X}$ & $\mathrm{X}$ & - \\
\hline C14 & - & $X$ & - & $X$ & $X$ & - & - & $\mathrm{X}$ & $X$ & - \\
\hline C15 & - & $X$ & $X$ & - & - & $X$ & - & $X$ & $X$ & - \\
\hline C16 & - & $X$ & - & $X$ & - & $X$ & - & $\mathrm{X}$ & $X$ & - \\
\hline C17 & $X$ & - & $X$ & - & $X$ & - & $X$ & - & - & $X$ \\
\hline C18 & $X$ & - & - & $X$ & $X$ & - & $X$ & - & - & $X$ \\
\hline C19 & $X$ & - & $X$ & - & - & $X$ & $X$ & - & - & $\mathrm{X}$ \\
\hline $\mathrm{C20}$ & $X$ & - & - & $X$ & - & $X$ & $\mathrm{X}$ & - & - & $\mathrm{X}$ \\
\hline C21 & $X$ & - & $X$ & - & $X$ & - & - & $X$ & - & $X$ \\
\hline C22 & $X$ & - & - & $X$ & $X$ & - & - & $X$ & - & $X$ \\
\hline $\mathrm{C} 23$ & $X$ & - & $X$ & - & - & $X$ & - & $X$ & - & $X$ \\
\hline $\mathrm{C} 24$ & $X$ & - & - & $X$ & - & $X$ & - & $\mathrm{X}$ & - & $\mathrm{X}$ \\
\hline C25 & - & $X$ & $X$ & - & $X$ & - & $X$ & - & - & $X$ \\
\hline C26 & - & $X$ & - & $X$ & $X$ & - & $X$ & - & - & $X$ \\
\hline C27 & - & $X$ & $X$ & - & - & $X$ & $X$ & - & - & $X$ \\
\hline $\mathrm{C} 28$ & - & $X$ & - & $X$ & - & $X$ & $\mathrm{X}$ & - & - & $\mathrm{X}$ \\
\hline C29 & - & $X$ & $\mathrm{X}$ & - & $\mathrm{X}$ & - & - & $X$ & - & $\mathrm{X}$ \\
\hline C30 & - & $X$ & - & $X$ & $X$ & - & - & $X$ & - & $X$ \\
\hline C31 & - & $X$ & $X$ & - & - & $X$ & - & $X$ & - & $X$ \\
\hline C32 & - & $X$ & - & $X$ & - & $X$ & - & $X$ & - & $X$ \\
\hline
\end{tabular}

Finally, climate zone and operational energy use demand is analyzed together because are directly linked. Generally, when the baseline operational energy demand is lower (warmer climates), the possibility to improve the energy performance by the refurbishment strategies is lower, increasing the 
importance of other building life cycle phases, and therefore increasing the relative difference between LCA and OSA methodologies.

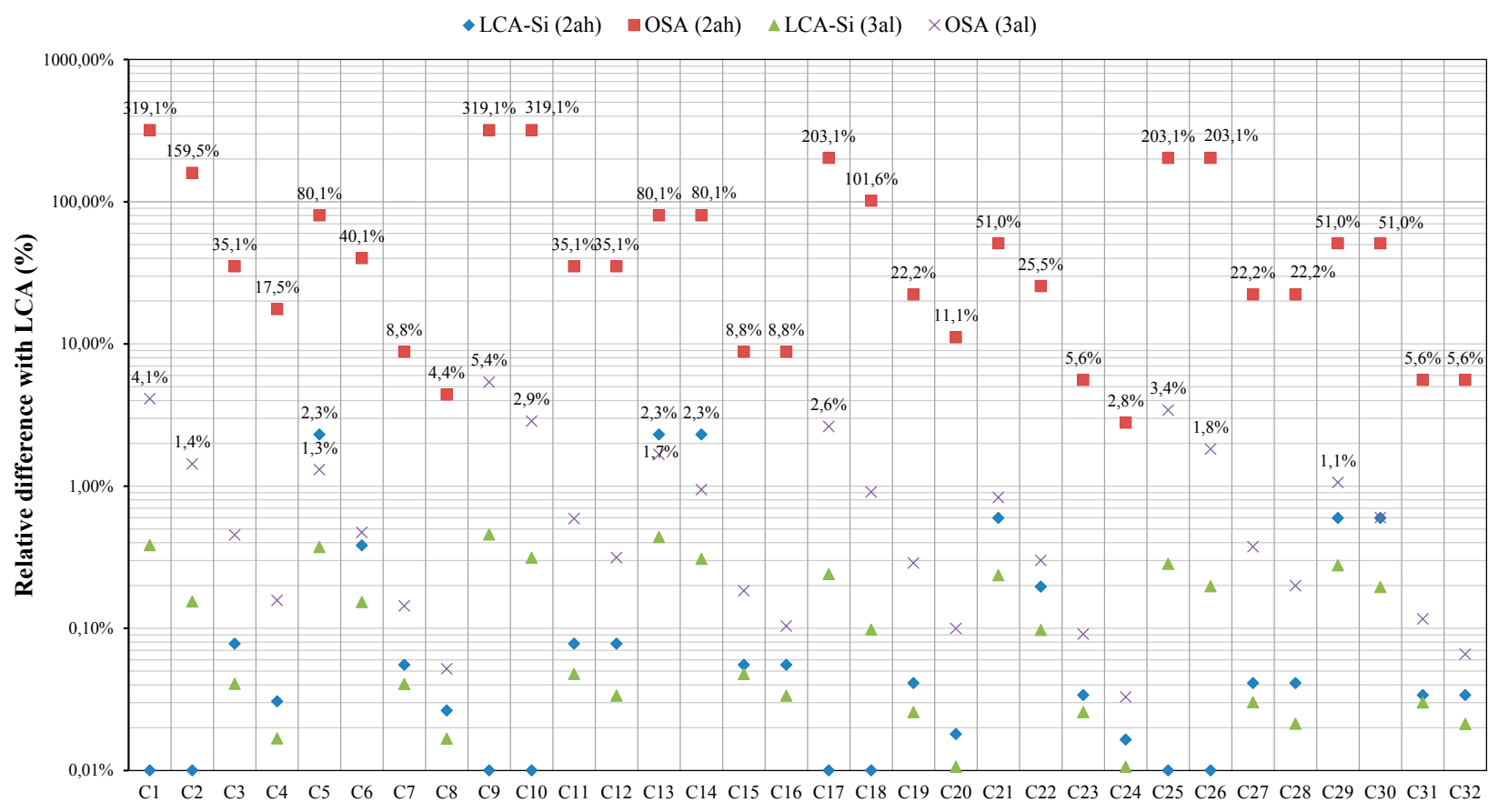

Figure 6. Relative difference with LCA for 2ah (advanced efficiency level ventilated façade system with high embodied energy products) and 3al (advanced efficiency level external insulation system with low embodied energy products) refurbishment strategies.

\subsection{Other Indicators and Environmental Impact Categories}

For simplicity, previous sections have presented only the NRPE results for the different refurbishment scenarios and using different calculation methodologies. However, as previously mentioned, a number of indicators need to be used in LCA to avoid potential shifting of impacts between different categories. Various previous studies as shown in Table 9 have studied different environmental impact categories.

Table 10 presents the results for additional environmental impact categories calculated for the case study. Differences between LCA and simplified methodologies are similar to the previously calculated for NRPE for indicators ADP and GWP, as it could be expected taking into account the strong correlations between these categories. For other frequently used environmental indicators such as ODP, POCP or AP, which are part of the indicators set in the CEN TC 350 standards [12], there is also a large similarity on the differences between methodologies, as the life cycle impacts on these categories are still strongly linked to the use of fossil fuels. For other impact categories not considered in this study or in the recent standardization efforts, for example those related to toxicity, further research is needed on the impact of all the different life cycle phases as there is currently not enough data available and results could differ in this case. 
Table 9. Environmental impact categories used in previous studies.

\begin{tabular}{|c|c|c|c|c|c|c|c|c|c|c|}
\hline Environmental impact categories & $\begin{array}{c}\text { Erlandsoona } \\
\text { et al., } 2004 \text { [27] }\end{array}$ & $\begin{array}{l}\text { Junnilla, } \\
2004[28]\end{array}$ & $\begin{array}{c}\text { Citherlet et al., } \\
2007[29] \\
\end{array}$ & $\begin{array}{c}\text { Zabalza et al., } \\
2009[30]\end{array}$ & $\begin{array}{c}\text { Utama et al., } \\
2009[31]\end{array}$ & $\begin{array}{c}\text { Kofoworola et al., } \\
2009 \text { [26] } \\
\end{array}$ & $\begin{array}{c}\text { Blom et al., } \\
2010[32]\end{array}$ & $\begin{array}{c}\text { Blengini et al., } \\
2010[33]\end{array}$ & $\begin{array}{l}\text { Gustavsoon et al., } \\
2010[34]\end{array}$ & $\begin{array}{c}\text { Hernandez } \\
\text { et al., } 2010 \text { [23] }\end{array}$ \\
\hline Resource use, primary energy, PE & - & - & - & $\mathrm{X}$ & $\mathrm{X}$ & $\mathrm{X}$ & - & $\mathrm{x}$ & $\mathrm{X}$ & $\mathrm{X}$ \\
\hline $\begin{array}{c}\text { Depletion of Abiotic resources, } \\
\text { elements, ADP-elements. }\end{array}$ & - & - & - & - & - & - & $\mathrm{X}$ & - & - & - \\
\hline Global warming, GWP & $\mathrm{X}$ & $\mathrm{X}$ & $\mathrm{X}$ & $\mathrm{X}$ & - & - & $\mathrm{X}$ & $\mathrm{X}$ & $\mathrm{X}$ & - \\
\hline Ozone Depletion, ODP & - & - & - & - & - & - & $\mathrm{X}$ & $\mathrm{x}$ & - & - \\
\hline $\begin{array}{c}\text { Photochemical Ozone } \\
\text { Creation, POCP } \\
\end{array}$ & $\mathrm{X}$ & - & $\mathrm{X}$ & - & - & - & $\mathrm{X}$ & $\mathrm{X}$ & - & - \\
\hline $\begin{array}{c}\text { Acidification for soil } \\
\text { and water, AP }\end{array}$ & $\mathrm{X}$ & $\mathrm{X}$ & $\mathrm{X}$ & - & - & - & $\mathrm{X}$ & $\mathrm{X}$ & - & - \\
\hline Eutrophication, EP & $\mathrm{X}$ & $\mathrm{X}$ & - & - & - & - & $\mathrm{X}$ & $\mathrm{X}$ & - & - \\
\hline Environmental impact categories & $\begin{array}{l}\text { Oritz et al., } \\
2010[35]\end{array}$ & $\begin{array}{l}\text { Dodoo et al., } \\
2010[36]\end{array}$ & $\begin{array}{l}\text { Malmqvist et al., } \\
\qquad 2011[37]\end{array}$ & $\begin{array}{l}\text { Rossi et al., } \\
2012[38]\end{array}$ & $\begin{array}{l}\text { Stephan et al., } \\
\quad 2012[24]\end{array}$ & $\begin{array}{c}\text { Ramesh } \text { et al., } \\
2012[39]\end{array}$ & $\begin{array}{l}\text { Stephan et al., } \\
2013[25]\end{array}$ & $\begin{array}{l}\text { Mosteiro et al., } \\
\quad 2014[40]\end{array}$ & $\begin{array}{c}\text { Dodoo et al., } \\
2014[41]\end{array}$ & - \\
\hline Resource use, primary energy, PE & - & $\mathrm{X}$ & - & - & $\mathrm{X}$ & $\mathrm{X}$ & $\mathrm{X}$ & $\mathrm{X}$ & $\mathrm{X}$ & - \\
\hline $\begin{array}{c}\text { Depletion of Abiotic resources, } \\
\text { elements, ADP-elements. }\end{array}$ & $\mathrm{X}$ & - & - & - & - & - & - & - & - & - \\
\hline Global warming, GWP & $\mathrm{X}$ & - & $\mathrm{X}$ & $\mathrm{X}$ & - & - & - & $\mathrm{x}$ & - & - \\
\hline Ozone Depletion, ODP & $\mathrm{X}$ & - & - & - & - & - & - & $\mathrm{X}$ & - & - \\
\hline $\begin{array}{c}\text { Photochemical Ozone } \\
\text { Creation, POCP }\end{array}$ & - & - & - & - & - & - & - & - & - & - \\
\hline $\begin{array}{l}\text { Acidification for soil } \\
\text { and water, AP }\end{array}$ & $\mathrm{X}$ & - & - & - & - & - & - & $\mathrm{x}$ & - & - \\
\hline Eutrophication, EP & - & - & - & - & - & - & - & $\mathrm{X}$ & - & - \\
\hline
\end{tabular}


Table 10. Results of the analysis for other impact indicators expressed for $\mathrm{m}^{2}$ and year. For abbreviations, refer to Table 9.

\begin{tabular}{|c|c|c|c|c|c|c|c|}
\hline \multicolumn{8}{|c|}{ Environmental impact reduction } \\
\hline \multirow{2}{*}{$\begin{array}{c}\text { Environmental Impact } \\
\text { Indicators (EII) }\end{array}$} & \multicolumn{3}{|c|}{ 2ah Strategy } & \multirow{2}{*}{ EII } & \multicolumn{3}{|c|}{ 3al Strategy } \\
\hline & LCA & LCA-Si & OSA & & LCA & LCA-Si & OSA \\
\hline ADP fossil fuels $\left(\mathrm{MJ} /\left(\mathrm{m}^{2} \cdot \mathrm{a}\right)\right)$ & 95 & 96 & 110 & ADP & 110 & 110 & 110 \\
\hline $\mathbf{G W P}\left(\mathrm{kg} \mathrm{CO}_{2} /\left(\mathrm{m}^{2} \cdot \mathrm{a}\right)\right)$ & 5.5 & 5.6 & 8.2 & GWP & 8.1 & 8.1 & 8.2 \\
\hline ODP $\left(\operatorname{kg~CFC~} 11 /\left(\mathrm{m}^{2} \cdot a\right)\right)$ & $2.5 \times 10^{-7}$ & $2.5 \times 10^{-7}$ & $2.1 \times 10^{-6}$ & OPD & $2.1 \times 10^{-6}$ & $2.1 \times 10^{-6}$ & $2.1 \times 10^{-6}$ \\
\hline POCP $\left(\mathrm{kg}\right.$ ethene $\left./\left(\mathrm{m}^{2} \cdot \mathrm{a}\right)\right)$ & $1.3 \times 10^{-3}$ & $1.3 \times 10^{-3}$ & $1.8 \times 10^{-3}$ & POCP & $1.8 \times 10^{-3}$ & $1.8 \times 10^{-3}$ & $1.8 \times 10^{-3}$ \\
\hline $\mathbf{A P}\left(\mathrm{kg} \mathrm{SO}_{2}-\mathrm{eq} /\left(\mathrm{m}^{2} \cdot \mathrm{a}\right)\right)$ & $2.4 \times 10^{-2}$ & $2.4 \times 10^{-2}$ & $2.9 \times 10^{-2}$ & $\mathbf{A P}$ & $2.9 \times 10^{-2}$ & $2.9 \times 10^{-2}$ & $2.9 \times 10^{-2}$ \\
\hline
\end{tabular}

\section{Discussion}

Simplifications of the LCA methodology can have important implications in decision-making process for selecting the most appropriate energy refurbishment solutions of existing buildings. The exercise previously developed, and especially the results obtained from the sensitivity analysis, provide useful information about how simplifications can bring insignificant or very remarkable uncertainties in comparison to a fully-fledged LCA methodology.

Differences between LCA and Simplified LCA are negligible in the case of assessing the use of Non-Renewable Primary Energy (NRPE) when comparing different refurbishment solutions oriented to reduce the energy consumption of existing buildings. The use of OSA does, however, have important limitations. For warm climates and ambitious goals for reducing the energy consumption of buildings by using materials and systems with a high energy embodied values, OSA is an oversimplified methodology and can mislead the decision making for choosing solutions with the best life cycle environmental performance. If products with low embodied energy are used, OSA, which studies only the reduction on energy use during the operational stage of the building, might be of sufficient accuracy. Of course, it should then be decided and benchmarked which materials are considered low embodied energy. In the case of colder climates or situations with drastic reductions on operational energy use due to a refurbishment strategy, values obtained with the OSA methodology will be very similar to those yielded by an LCA, as relative importance of products and other building life cycle phases is lower. In addition, OSA is not recommended if construction products and systems with short Estimated Service Life are used.

Regarding the quantity and type of environmental indicators used on the analysis, it has to be considered that when applying LCA to compare different options, commonly there is not a specific alternative that scores the best in all the impact categories. Therefore, the decision maker needs to select the best option according to his/her environmental values and objectives and apply some kind of weighting among the different impact categories. This study is focused on the NRPE Indicator as it generally offers a good correlation with other related impact categories (such as Global Warming and Abiotic Depletion of fossil fuels) and, on the other hand, captures the consequences of applying energy efficiency strategies. Other environmental impact categories not so correlated to the use of fossil use (such as toxicity) are not well represented by this indicator.

The source of data used in the LCA has a remarkable influence increasing the uncertainty of the results, as significant differences exist in the calculations using data derived from process inventories 
(e.g., from Ecoinvent and $\mathrm{GaBi}$ databases, for instance, or from EPDs) or from hybrid Input-Output analysis This observation is in line with previous studies from Crawford [57] and Stephan et al. [25] which have demonstrated that the truncation error associated to process-based life cycle inventories may significantly affect the final results.

Regarding data associated to the construction stage, the main barrier is again related to the lack and uncertainty of environmental information, which largely depends on project specific parameters and are difficult to assess for a set of different strategies. As for data associated for transportation, technicians usually have information on the exact location of the distributor of the product or system applied in the refurbishment project, but in many cases the manufacturing location is unknown, being the impacts associated to transport from manufacturer to distributor difficult to calculate. Due to the lack of information about future waste management processes, the uncertainty of the end of life stage is also very large.

Finally, it is important to mention that despite heating being one of the major contributors to the operational energy consumption of buildings, cooling of indoor spaces (especially in warm climate zones) should not be left out of the scope of the assessment of energy refurbishment in any case (LCA, LCA-Si or OSA) as, for some scenarios, it can have a significant influence on the decision-making process.

\section{Conclusions}

The refurbishment of the existing building stock with the aim of reducing its operational energy consumption is being fostered for different reasons and by different actors in the EU. The intense standardization efforts on the assessment of the sustainability of buildings carried out by the European Committee for Standardization Technical Committee 350 [12] suggests that the application of the life cycle approach will be more common in the near future. In this context, simplified LCA (LCA-Si) could be seen as a first step towards a comprehensive and extensive application of LCA within the construction sector. On the other hand, depending on the objectives pursued and the resources available, the practical application of the LCA methodology could be neither necessary nor possible, and in some circumstances an analysis of the energy reduction derived from the refurbishment during the operational stage (OSA) could be sufficient. As proved through a complete case study, in the case of assessing different refurbishment strategies oriented to reduce the energy consumption of buildings, a simplified LCA study may underestimate the absolute energy values, but it generally allows identifying the most (life-cycle) efficient solution. However, considering only the operational energy use (OSA) may lead to the selection of less efficient solutions.

The application of the fully-fledged LCA methodology still faces important challenges, and the construction industry needs to play a key role in the calculation and publication of data to facilitate accurate assessments of building energy refurbishment projects.

\section{Acknowledgments}

This paper is part of the $\mathrm{PhD}$ research of Xabat Oregi Isasi who thanks the Basque Government for the financial support given for his $\mathrm{PhD}$ research. All the authors acknowledge the contribution of reviewers to improve the text. 


\section{Author Contributions}

The paper is based on Xabat Oregi's PhD research work. Oregi was responsible for the research design, data collection and analyses. Patxi Hernandez and Cristina Gazulla provided guidance and supervision respectively. Marina Isasa provided additional insights.

\section{Conflicts of Interest}

The authors declare no conflict of interest.

\section{References}

1. International Energy Agency (IEA). $\mathrm{CO}_{2}$ emissions from fuel combustion Highlights; IEA: Paris, France, 2013; p. 600.

2. Power, A. Does demolition or refurbishment of old and inefficient homes help to increase our environmental, social and economic viability? Energy Policy 2008, 36, 4487-4501.

3. IEE Project TABULA (2009-2012). Available online: http://episcope.eu/iee-project/tabula/ (accessed on 5 February 2015).

4. Sharma, A.; Saxena, A.; Sethi, M.; Shree, V.; Varun. Life cycle assessment of buildings: A review. Renew. Sustain. Energy Rev. 2011, 15, 871-875.

5. Ramesh, T.; Prakash, R.; Shukla, K.K. Life cycle energy analysis of buildings: An overview. Energy Build. 2010, 10, 1592-1600.

6. Chang, Y.; He, C.Q.; Tang, B.J.; Wei, Y.M. China's energy consumption in the building sector: A life cycle approach. Energy Build. 2015, 94, 240-251.

7. Richman, R.; Pasqualini, P.; Kirsh, A. Life-cycle analysis of roofing insulation levels for cold storage buildings. J. Archit. Eng. 2009, 15, 55-61.

8. Karimpour, M.; Belusko, M.; Xing, K.; Bruno, F. Minimising the life cycle energy of buildings: Review and analysis. Build. Environ. 2014, 73, 106-114.

9. Cellura, M.; Guarino, F.; Longo, S.; Mistretta, M. Energy life-cycle approach in net zero energy buildings balance: Operation and embodied energy of an Italian case study. Energy Build. 2014, 72, 371-381.

10. Lützkendorf, T.; Foliente, G.; Balouktsi, M.; Wiberg, A.H. Net-zero buildings: Incorporating embodied impacts. Build. Res. Inf. 2014, 43, 62-81.

11. ISO/TC 59/SC 17. Sustainability in Buildings and Civil Engineering Works; British Standards Institution: London, UK, 2014.

12. CEN TC 350. European Committee for Standardization, Technical Committees. Sustainability of Construction Works. Available online: http://portailgroupe.afnor.fr/public_espacenormalisation/ centc350/index.html (accessed on 30 April 2015).

13. Cabeza, L.F.; Rincón, L.; Vilariño, V.; Pérez, G.; Castell, A. Life cycle assessment (LCA) and life cycle energy analysis (LCEA) of buildings and the building sector: A review. Renew. Sustain. Energy Rev. 2014, 29, 394-416.

14. Chau, C.K.; Leung, T.M.; Ng, W.Y. A review on life cycle assessment, life cycle energy assessment and life cycle carbon emissions assessment on buildings. Appl. Energy 2015, 143, 395-413. 
15. European Commission. Resource Efficiency Opportunities in the Building Sector. COM (2014) 445 Final. Brussels, 1.7.2014. Available online: http://ec.europa.eu/environment/eussd/pdf/Sustainable BuildingsCommunication.pdf (accessed on 5 February 2015).

16. UNE-EN ISO 14040:2006. Environmental Management_Life Cycle Assessment_Principles and Framework; The International Organization for Standardization (ISO): Geneva, Switzerland, 2010.

17. UNE-EN ISO 14044:2006. Environmental Management_Life Cycle Assessment-Requirements and Guidelines; The International Organization for Standardization (ISO): Geneva, Switzerland, 2010.

18. Guinée, J.B.; Gorrée, M.; Heijungs, R.; Huppes, G.; Kleijn, R.; de Koning, A.; van Oers, L.; Sleeswijk, A.W.; Suh, S.; Helias, A.; et al. Life Cycle Assessment-An Operational Guide to the ISO Standards; Centre for Environmental Studies (CML), Leiden University: Leiden, The Netherland, 2011.

19. Goedkoop, M.; Spriensma, R. The Eco-indicator 99. A Damage Oriented Method for Life Cycle Assessment; Pre-Consultants: Amersfoot, The Netherlands, 2001.

20. EN 15978:2011. Sustainability of Construction Works-Assessment of Environmental Performance of Buildings - Calculation Method. Available online: http://standards.cen.eu/dyn/www/ $\mathrm{f}$ ? $\mathrm{p}=204: 110: 0::::$ FSP_PROJECT:31325\&cs=16BA443169318FC086C4652D797E50C47 (accessed on 5 February 2015).

21. Wadel, G.; López, F.; Sagrera, A.; Prieto, J. Refurbishment considering environmental bimpact reduction targets: A test case for a multiple-family dwelling in the area of Playa de Palma, Mallorca. Inf. Constr. 2011, 63, 89-102

22. Crowther, P. Design for Disassembly to Recover Embodied Energy. In Proceedings of the 16th International Conference on Passive and Low-Energy Architecture, Melbourne, Australia, 22-24 September 1999.

23. Hernandez, P.; Kenny, P. From net energy to zero energy buildings: Defining life cycle zero energy buildings (LC-ZEB). Energy Build. 2010, 42, 815-821.

24. Stephan, A.; Crawford, R.H.; Myttenaere, K. Towards a comprehensive life cycle energy analysis framework for residential buildings. Energy Build. 2012, 55, 592-600.

25. Stephan, A.; Crawford, R.H.; Myttenaere, K. A comprehensive assessment of the life cycle energy demand of passive houses. Appl. Energy 2013, 112, 23-34.

26. Kofoworola, O.; Gheewala, S. Life cycle energy assessment of a typical office building in Thailand. Energy Build. 2009, 4, 1076-1083.

27. Erlandssona, M.; Levin, P. Environmental assessment of rebuilding and possible performance improvements effect on a national scale. Build. Environ. 2004, 39, 1453-1465.

28. Junnila, S. The Environmental Impact of an Office Building throughout its Life Cycle. Ph.D. Thesis, Helsinki University of Technology, Espoo, Finland, 2004.

29. Citherlet, S.; Defaux, T. Energy and environmental comparison of three variants of a family house during its whole life span. Build. Environ. 2007, 42, 591-598.

30. Zabalza, I.; Aranda, A.; Scarpellini, S. Life cycle assessment in buildings: State-of-the-art and simplified LCA methodology as a complement for building certification. Build. Environ. 2009, 44, 2510-2520.

31. Utama, A.; Gheewala, S.H. Indonesian residential high rise buildings: A life cycle energy assessment. Energy Build. 2009, 41, 1263-1268. 
32. Blom, I.; Itard, L.; Meijer, A. Environmental impact of dwellings in use: Maintenance of façade components. Build. Environ. 2010, 45, 2526-2538.

33. Blengini, G.A.; Di Carlo, T. The changing role of life cycle phases, subsystems and materials in the LCA of low energy buildings. Energy Build. 2010, 42, 869-880.

34. Gustavsson, L.; Joelsson, A. Life cycle primary energy analysis of residential buildings. Energy Build. 2010, 42, 210-220.

35. Ortiz-Rodriguez, O.; Castells, F.; Sonnemann, G. Life cycle assessment of two dwellings: One in Spain, a developed country, and one in Colombia, a country under development. Sci. Total Environ. 2010, 408, 2435-2443.

36. Dodoo, A.; Gustavsson, L.; Sathre, R. Life cycle primary energy implication of retrofitting a wood-framed apartment building to passive house standard. Resour. Conserv. Recycl. 2010, 54, 1152-1160.

37. Malmqvist, T.; Galumann, M.; Scarpellini, S.; Zabalza, I.; Aranada, A.; Llera, E.; Diaz, S. Life cycle assessment in buildings: The ENSLIC simplified method and guidelines. Energy 2011, 36, 1900-1907.

38. Rossi, B.; Marique, A.F.; Glaumann, M.; Reiter, S. Life-cycle assessment of residential buildings in three different European locations, basic tool. Build. Environ. 2012, 51, 395-401.

39. Ramesh, T.; Prakash, R.; Shukla, K.K. Life cycle energy analysis of a residential building with different envelopes and climates in Indian context. Appl. Energy 2012, 89, 193-202.

40. Mosteiro-Romero, M.; Krogmann, U.; Wallbaum, H.; Ostermeyer, Y.; Senick, J.S.; Andrews, C.J. Relative importance of electricity sources and construction practices in residential buildings: A Swiss-US comparison of energy related life-cycle impacts. Energy Build. 2014, 68, 620-631.

41. Dodoo, A.; Gustavsson, L.; Sathre, R. Lifecycle primary energy analysis of low-energy timber building systems for multi-storey residential buildings. Energy Build. 2014, 81, 84-97.

42. Spanish Technical Building Code, CTE, 2013. Available online: http://www.codigotecnico.org/ (accessed on 5 February 2015).

43. Design Builder Simulation Tool. Available online: http://www.designbuilder.es (accessed on 5 February 2015).

44. ASHRAE International Weather Files for Energy Calculations 2.0 (IWEC2). Available online: https://www.ashrae.org/resources--publications/bookstore/iwec2 (accessed on 5 February 2015).

45. Ecoinvent Centre. Swiss Centre for Life Cycle Inventories. Düberdorf, Suiza. Available online: http://www.ecoinvent.org/database/ecoinvent-version-3/ (accessed on 5 February 2015).

46. International Passive House Association. Available online: http://www.passivehouse-international. org/index.php?page_id=150 (accessed on 5 February 2015).

47. GaBi. Product Sustainability Performance Solutions by PE International. Available online: http://www.gabi-software.com/databases/gabi-databases/ (accessed on February 2015).

48. Wittstock, B.; Gantner, J.; Lenz, K.; Saunders, T.; Anderson, J.; Carter, C.; Gyetvai, Z.; Kreißig, J.; Braune, A.; Lasvaux, S.; et al. EeBGuide Guidance Document. Part B: Buildings. Operational Guidance for Life Cycle Assessment Studies of the Energy-Efficient Buildings Initiative 2011. Available online: http://www.eebguide.eu/?page_id=704 (accessed on 5 February 2015). 
49. ISO 15686-8:2008. Buildings and Constructed Assets-Service-life Planning-Part 8: Reference Service Life and Service-Life Estimation. Available online: http:/www.iso.org/iso/iso_catalogue/ catalogue_tc/catalogue_detail.htm?csnumber=39070 (accessed on February 2015).

50. National association of Home Builders (NAHB) \& and Bank of America. Study of Life Expectancy of Home Materials, 2007. Available online: https://www.nahb.org/ (accessed on 5 February 2015).

51. Winistorfer, P.; Chen, Z.; Lippke, B.; Stevens, N. Energy consumption and greenhouse gas emissions related to the use, maintenance, and disposal of a residential structure. Wood Fiber Sci. 2007, 37, 128-139.

52. Saint-Gobain Glass. Declaration Environnementale et Sanitarie. SGG CLIMAPLUS. AFNOR Registrierungsnummer $\quad \mathrm{N}^{\circ}$ 08-257:2011. Available online: http://www.inies.fr/Upload/ 2261_sgg_climaplus_4s_fr_v2.2_05_2012.pdf (accessed on February 2015).

53. Saint-Gobain Glass. Declaration Environnementale et Sanitarie SGG CLIMATOP AFNOR: 08-259:2011. Available online: http://epd.saint-gobain-glass.com/ (accessed on February 2015).

54. CORMO. S3 Window in Solid Swedish Pinewood Double Leaves. Available online: http://gryphon.environdec.com/data/files/6/9218/epd142_20130408.pdf (accessed on February 2015).

55. A Comparison of Emissions Factors for Electricity Generation; Department of Energy \& Climate Change: London, UK, 2013.

56. Treloar, G.J. Extracting embodied energy paths from input-output tables: Towards an input-outputbased hybrid energy analysis method. Econ. Syst. Res. 1997, 9, 375-391.

57. Crawford, R.H. Validation of a hybrid life-cycle inventory analysis method. J. Environ. Manag. 2008, 88, 496-506.

58. Crawford, R.H. Life Cycle Assessment in the Built Environment; Spon Press: London, UK, 2011.

59. Crawford, R.; Stephan, A. The Significance of Embodied Energy in Certified Passive Houses. In Proceedings of the International Conference on Construction and Building Materials, Copenhagen, Denmark, 13-14 June 2013; pp. 473-479.

60. Stephan, A.; Stephan, L. Reducing the total life cycle energy demand of recent residential buildings in Lebanon. Energy 2014, 74, 618-637.

61. Topouzi, M. The Effect of "Default User" Inputs in Modelling Tools and Methods in Energy Use. In Proceedings of the PLEA 2011-27th International Conference on Passive and Low-Energy Architecture, Louvain-la-Neuve, Belgium, 13-15 July 2011; pp. 35-40.

62. Juodis, E.; Jaraminiene, E.; Dudkiewicz, E. Inherent variability of heat consumption in residential buildings. Energy Build. 2009, 11, 1188-1194.

(C) 2015 by the authors; licensee MDPI, Basel, Switzerland. This article is an open access article distributed under the terms and conditions of the Creative Commons Attribution license (http://creativecommons.org/licenses/by/4.0/). 